\title{
Distribution of hydrogen peroxide and formaldehyde over Central Europe during the HOOVER project
}

\author{
T. Klippel ${ }^{1}$, H. Fischer ${ }^{1}$, H. Bozem ${ }^{1}$, M. G. Lawrence ${ }^{1}$, T. Butler ${ }^{1}$, P. Jöckel ${ }^{1}{ }^{* *}$, H. Tost ${ }^{1}$, M. Martinez ${ }^{1}$, H. Harder ${ }^{1}$, \\ E. Regelin ${ }^{1}$, R. Sander ${ }^{1}$, C. L. Schiller ${ }^{1,2}$, A. Stickler ${ }^{1, *}$, and J. Lelieveld ${ }^{1}$ \\ ${ }^{1}$ Department of Atmospheric Chemistry, Max Planck Institute for Chemistry, Mainz, Germany \\ ${ }^{2}$ Department of Chemistry, York University, Toronto, Canada \\ * now at: Oeschger Centre for Climate Change Research and Institute for Geography, Univ. Bern, Switzerland \\ ** now at: Deutsches Zentrum für Luft und Raumfahrt (DLR), Institut für Physik der Atmosphäre, Oberpfaffenhofen, Germany
}

Received: 5 November 2010 - Published in Atmos. Chem. Phys. Discuss.: 6 January 2011

Revised: 26 April 2011 - Accepted: 28 April 2011 - Published: 11 May 2011

\begin{abstract}
In this study we report measurements of hydrogen peroxide $\left(\mathrm{H}_{2} \mathrm{O}_{2}\right)$, methyl hydroperoxide* (MHP* as a proxy of MHP based on an unspecific measurement of total organic peroxides) and formaldehyde ( $\mathrm{HCHO}$ ) from the $\mathrm{HO}_{\mathrm{x}}$ OVer EuRope (HOOVER) project $\left(\mathrm{HO}_{\mathrm{x}}=\mathrm{OH}+\mathrm{HO}_{2}\right)$. HOOVER included two airborne field campaigns, in October 2006 and July 2007. Measurement flights were conducted from the base of operation Hohn (Germany, $54^{\circ} \mathrm{N}, 9^{\circ} \mathrm{E}$ ) towards the Mediterranean and to the subpolar regions over Norway. We find negative concentration gradients with increasing latitude throughout the troposphere for $\mathrm{H}_{2} \mathrm{O}_{2}$ and $\mathrm{CH}_{3} \mathrm{OOH} *$. In contrast, observed $\mathrm{HCHO}$ is almost homogeneously distributed over central and northern Europe and is elevated over the Mediterranean. In general, the measured gradients tend to be steepest entering the Mediterranean region, where we also find the highest abundances of the 3 species. Mixing ratios of these tracers generally decrease with altitude. $\mathrm{H}_{2} \mathrm{O}_{2}$ and $\mathrm{CH}_{3} \mathrm{OOH} *$ show maxima above the boundary layer at $2-5 \mathrm{~km}$, being more distinct over southern than over northern Europe.

We also present a comparison of our data with simulations by two global 3-D-models, MATCH-MPIC and EMAC, and with the box model CAABA. The models realistically represent altitude and latitude gradients for both $\mathrm{HCHO}$ and hydroperoxides (ROOH). In contrast, the models have problems reproducing the absolute mixing ratios, in particular of $\mathrm{H}_{2} \mathrm{O}_{2}$. Large uncertainties about retention coefficients and
\end{abstract}

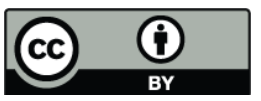

Correspondence to: H. Fischer (horst.fischer@mpic.de) cloud microphysical parameters suggest that cloud scavenging might be a large source of error for the simulation of $\mathrm{H}_{2} \mathrm{O}_{2}$. A sensitivity study with EMAC shows a strong influence of cloud and precipitation scavenging on the budget of $\mathrm{H}_{2} \mathrm{O}_{2}$ as simulations improve significantly with this effect switched off.

\section{Introduction}

Atmospheric $\mathrm{H}_{2} \mathrm{O}_{2}$ gained attention in the late 1970s, when it was identified as one of the key oxidants of sulfur dioxide $\left(\mathrm{SO}_{2}\right)$ in cloud droplets (for $\mathrm{pH}<4.5$ ) leading to acidification of cloud water and subsequently to acid precipitation, which was a major environmental issue (Penkett et al., 1979; Robbin Martin and Damschen, 1981; Kunen et al., 1983; Calvert et al., 1985). Today it is clear that besides being an important oxidant, $\mathrm{H}_{2} \mathrm{O}_{2}$ and the organic peroxides, together with $\mathrm{HCHO}$, play an important role as reservoir species for the $\mathrm{HO}_{\mathrm{x}}$ family, thus modulating the oxidation power and self cleaning capacity of the atmosphere (Lelieveld and Crutzen, 1990; Crutzen et al., 1999). As $\mathrm{HO}_{\mathrm{x}}$ reservoir species they are also directly linked to the chemistry of ozone in the atmosphere. Gaseous $\mathrm{H}_{2} \mathrm{O}_{2}$ is formed mainly via recombination of $\mathrm{HO}_{2}$ radicals (Logan et al., 1981; Kleinman, 1986). The smallest organic peroxide, $\mathrm{CH}_{3} \mathrm{OOH}$, being also the dominant one in remote marine areas and the free troposphere, is formed by the reaction of $\mathrm{CH}_{3} \mathrm{OO}$ with $\mathrm{HO}_{2}$. The main source of $\mathrm{HO}_{2}$ is the oxidation of carbon monoxide (CO) by OH (Lightfoot et al., 1992). It is also generated by the photolysis of $\mathrm{HCHO}$ and other

Published by Copernicus Publications on behalf of the European Geosciences Union. 
aldehydes. $\mathrm{CH}_{3} \mathrm{OO}$ is mainly produced during the oxidation of methane $\left(\mathrm{CH}_{4}\right)$, also initiated by reaction with $\mathrm{OH}$ (Atkinson, 1994). Both radicals, $\mathrm{HO}_{2}$ and $\mathrm{CH}_{3} \mathrm{OO}$, react faster with NO than with themselves. Therefore, the production of peroxides is determined by the $\mathrm{OH}$ abundance and also by the ambient NO mixing ratios (Lee et al., 2000). Above about 100 picomole (pmol) mole ${ }^{-1}(\mathrm{~mol})$ of $\mathrm{NO}$ the production of peroxides is effectively suppressed by the reaction of $\mathrm{HO}_{2}$ with $\mathrm{NO}$ and below about $100 \mathrm{pmol} \mathrm{mol}^{-1} \mathrm{NO}$ the production of peroxides is directly determined by the photolysis of $\mathrm{O}_{3}$ in the presence of water vapour accounting for the main atmospheric production of $\mathrm{OH}$ (Lee et al., 2000). The latter reaction together with the photolysis of $\mathrm{H}_{2} \mathrm{O}_{2}, \mathrm{CH}_{3} \mathrm{OOH}$, $\mathrm{HCHO}$ and partially oxidised volatile organic compounds (VOCs) form the primary $\mathrm{HO}_{\mathrm{x}}$ sources in the atmosphere (Lee et al., 2000). With increasing latitude and altitude the decreasing concentration of water vapour, as a radical precursor, becomes a limiting factor for $\mathrm{HO}_{\mathrm{x}}$ production. In these regions, the photolyses of $\mathrm{ROOH}$ and $\mathrm{HCHO}$ become more important as a sources of $\mathrm{HO}_{\mathrm{x}}$ (Jaeglé et al., 1997, 2000; Faloona et al., 2000). Over North America for example, the $\mathrm{HO}_{x}$ production is dominated by the photolysis of $\mathrm{O}_{3}$ in the presence of water vapour at low latitudes and by the photolysis of HCHO at higher latitudes (Weinstein-Lloyd et al., 1998; Cantrell et al., 2003; Snow et al., 2003). Nevertheless, although peroxides can be an important $\mathrm{HO}_{\mathrm{x}}$ source, their relatively high solubility and hence their sensitivity to deposition processes can also make them an efficient sink for $\mathrm{HO}_{\mathrm{x}}$.

$\mathrm{HCHO}$ is a key intermediate formed during the oxidation of biogenic and anthropogenic VOCs. In the remote parts of the atmosphere $\mathrm{HCHO}$ is produced mainly by the oxidation of $\mathrm{CH}_{4}$ through reaction with $\mathrm{OH}$. Similar to the peroxides, the photolysis of $\mathrm{HCHO}$ yields $\mathrm{HO}_{2}$ radicals. Together with the peroxides $\mathrm{HCHO}$ can contribute up to $30 \%$ to the total $\mathrm{HO}_{\mathrm{x}}$ sources (Lee et al., 1997).

Typically, $\mathrm{ROOH}$ and $\mathrm{HCHO}$ have higher mixing ratios in the lower troposphere and mixing ratios decrease with altitude due to the fact that the radical concentrations decrease along with water vapour (Heikes et al., 1996b). However, $\mathrm{H}_{2} \mathrm{O}_{2}$ does not show a simple decline of mixing ratios with altitude. Instead a maximum above the planetary boundary layer (PBL) at $2-5 \mathrm{~km}$ height is often observed (Daum et al., 1990; Heikes, 1992; Weinstein-Lloyd et al., 1998; Snow et al., 2003, 2007). Due to strong mixing within the PBL, air masses near the surface are strongly affected by $\mathrm{H}_{2} \mathrm{O}_{2}$ dry deposition. In addition, $\mathrm{H}_{2} \mathrm{O}_{2}$ is removed by rainout in the lower troposphere (Heikes et al., 1996b; Hall and Claiborn, 1997; Hall et al., 1999). The combination of these effects results in an inverted "C-shaped" vertical profile for $\mathrm{H}_{2} \mathrm{O}_{2}$. However, more polluted conditions, especially in the boundary layer, lead to a more complex mechanism for the formation of $\mathrm{H}_{2} \mathrm{O}_{2}$ and hence to higher variabilities in this region (Nunnermacker et al., 2008). A similar, but weaker maximum at $2-5 \mathrm{~km}$ can be found for $\mathrm{CH}_{3} \mathrm{OOH}$ (Palenik et al., 1987; Weinstein-Lloyd et al., 1998; Snow et al., 2003, 2007). General altitude profiles of $\mathrm{CH}_{3} \mathrm{OOH}$ are flatter than those of $\mathrm{H}_{2} \mathrm{O}_{2}$ because $\mathrm{CH}_{3} \mathrm{OOH}$ is less sensitive to rainout processes and deposition due to its lower solubility.

$\mathrm{HCHO}$ profiles observed in previous field campaigns show an almost exponential decline of mixing ratios with height (Arlander et al., 1995; Heikes et al., 2001; Fried et al., 2003a,b; Kormann et al., 2003; Snow et al., 2007). However, increased HCHO mixing ratios for the upper troposphere (UT) have been reported in certain cases (Fried et al., 2003a; Kormann et al., 2003; Stickler et al., 2006). These have been explained as a result of upward transport through convective updrafts or long range transport of air masses with enhanced levels of reactive hydrocarbons or primary HCHO. Additionally, Stickler et al. (2006) have shown that enhanced $\mathrm{NO}_{\mathrm{x}}\left(=\mathrm{NO}+\mathrm{NO}_{2}\right)$ levels at these altitudes increase the production of $\mathrm{HCHO}$.

The mixing ratios of peroxides generally decrease with increasing latitude, which can at least partially be explained by decreasing water vapour and lower zenith angles, resulting in a reduced solar radition flux (Jacob and Klockow, 1992; Perros, 1993; Slemr and Tremmel, 1994; Snow et al., 2003, 2007). A similar latitudinal behaviour can be expected for $\mathrm{HCHO}$, which was indeed found in the marine boundary layer (Arlander et al., 1995; Weller et al., 2000; Fried et al., 2002, 2003a) but is less pronounced in the upper troposphere (Dufour et al., 2009).

Section 2 provides an introduction to the HOOVER project, the framework of the measurements presented here, followed by the experimental Sect. 3. Section 4 presents and discusses the data in comparison to former field campaigns from the literature and to simulations by two global models and the box model.

\section{The HOOVER project}

The objective of the HOOVER project was to characterise the spatial distribution and seasonal variation of a suite of chemical tracers over Europe. Two airborne measurement campaigns were carried out in October 2006 and July 2007 covering an area from the Mediterranean region in the south (appr. $30^{\circ} \mathrm{N}$ ) up to the subpolar regions north of Norway (appr. $75^{\circ} \mathrm{N}$ ). A total of 13 measurement flights were conducted during both HOOVER campaigns. Flight tracks of the HOOVER missions are shown in Fig. 1 together with flight tracks from the Upper Tropospheric Ozone: Processes Involving $\mathrm{HO}_{\mathrm{x}}$ And $\mathrm{NO}_{\mathrm{x}}$ : The Impact of Aviation and Convectively Transported Pollutants in the Tropopause Region (UTOPIHAN-ACT) project which will be used for comparison. The central aspect of the HOOVER missions as indicated by the project name was to understand the control of $\mathrm{HO}_{\mathrm{x}}$ as the main atmospheric oxidant, including reservoir and precursor species such as $\mathrm{H}_{2} \mathrm{O}_{2}, \mathrm{CH}_{3} \mathrm{OOH} *$ and $\mathrm{HCHO}$. With the exception of HOOVER flight 08 , which was 


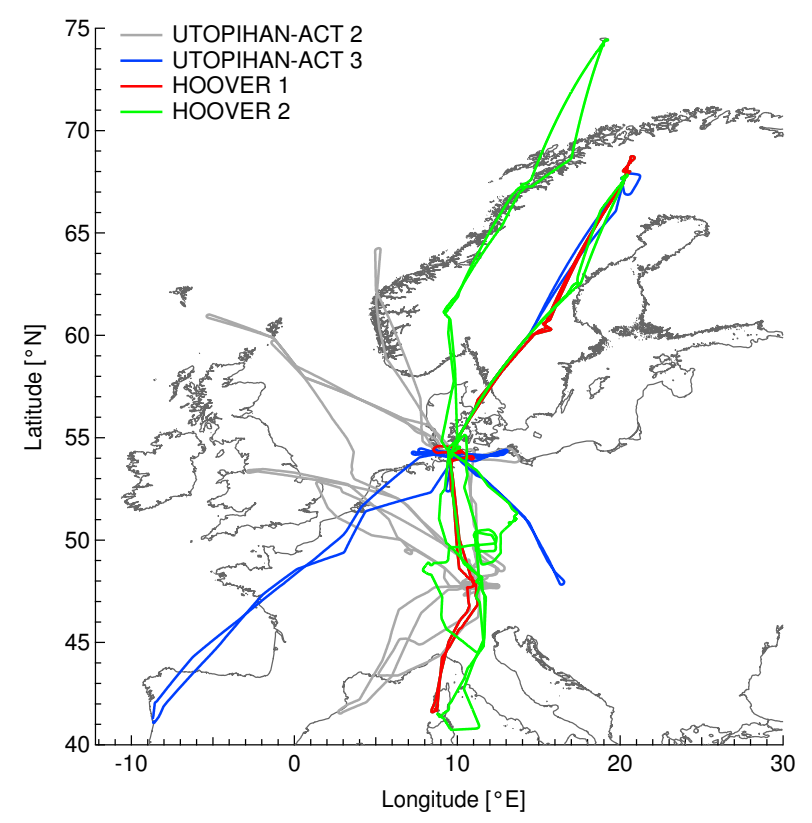

Fig. 1. Flight tracks of the measurement campaigns UTOPIHANACT 2 (July 2003), UTOPIHAN-ACT 3 (March 2004), HOOVER 1 (October 2006) and HOOVER 2 (July 2007) over Europe.

dedicated to measure the inflow and outflow of a convective system, HOOVER measured "background" photochemical conditions. In order to obtain vertical information on trace gases in the troposphere a flight scheme with an intermediate "dive", in addition to profiles at the final destinations, was added. As an example, the HOOVER flight 10 is shown in Fig. 2. The upper left panel shows an altitude vs. latitude plot with the standard flight profile and the intermediate dive. In the other plots mixing ratios of key species are colour coded on altitude profiles, indicating a stratospheric intrusion in the black box during the early part of flight $10 . \mathrm{CO}$ and $\mathrm{O}_{3}$ are anticorrelated during this part of the flight and the peroxides show particularly low values. The modelled potential vorticity for this flight shown in the upper right panel strengthens the interpretation of the observations as due to stratospheric injection. Throughout the manuscript, however, the dataset has been filtered for stratospheric influences by removing all data points with $\mathrm{O}_{3}$ higher than $100 \mathrm{nmol} \mathrm{mol}^{-1}$, in order to establish a tropospheric data set.

\section{Methods}

\subsection{Measurements of $\mathrm{H}_{2} \mathrm{O}_{2}$ and $\mathrm{CH}_{3} \mathrm{OOH} *$}

$\mathrm{H}_{2} \mathrm{O}_{2}$ and $\mathrm{CH}_{3} \mathrm{OOH} *$ were measured with a wet chemical system based on the technique described by Lazrus et al. (1985, 1986). Ambient air is collected via a $1 / 2^{\prime \prime}$ PFA tubing embedded inside a stainless steel inlet system that is mounted front-facing on a side window of a Learjet 35A of
GFD (Gesellschaft für Flugzieldarstellung, Hohn, Germany). The $1 / 2^{\prime \prime}$ tubing is set up as a bypass loop that brings air into and out of the cabin. Two instruments are connected to this bypass, the peroxide monitor and an IR laser spectrometer used to measure $\mathrm{HCHO}$ as described below. For the peroxide measurements, the air is sampled from the bypass by a teflon coated membrane pump (MD1, Vacuubrand, Wertheim, Germany) to achieve a constant pre-pressure for the actual measurement. The pressure was held at $1050 \mathrm{hPa}$ by a microcontroller (V25, custom built, electronics department, MPI-C) adjusting the pump speed and two adjustable solenoid blowoff valves (Teqcom, Santa Ana, USA). After pressurising, the collected air enters the AL2001 CA peroxide monitor (AEROLASER, Garmisch-Partenkirchen, Germany) and passes over a buffered (potassium hydrogen phthalate/ $\mathrm{NaOH}$ ) sampling solution ( $\mathrm{pH}$ 5.8) in a glass stripping coil. Due to their high solubility the peroxide molecules dissolve into the stripping solution with a stripping efficiency of $\approx 100 \%$ for $\mathrm{H}_{2} \mathrm{O}_{2}$ and $\approx 60 \%$ for $\mathrm{CH}_{3} \mathrm{OOH}$. The resulting $\mathrm{ROOH}$ solution is then divided into two channels and subsequently reacted with p-hydroxyphenyl acetic acid (POPHA) and horseradish peroxidase. The reaction yields the fluorescent dye 6,6'-dihydroxy-3,3'-biphenyldiacetic acid, a dimer of POPHA, in stoichiometric quantities which is then measured by means of fluorescence spectroscopy. Excitation of the dye with a Cd pen ray lamp at $326 \mathrm{~nm}$ is followed by measurement of the resulting fluorescence at 400-420 nm with a photomultiplier tube (Hamamatsu Photonics, Herrsching, Germany). In channel $\mathrm{B}$, prior to the reaction of the peroxides with POPHA, $\mathrm{H}_{2} \mathrm{O}_{2}$ is selectively destroyed with catalase. Hence, channel A delivers the total ROOH mixing ratios while channel $\mathrm{B}$ delivers the difference between $\mathrm{ROOH}$ and $\mathrm{H}_{2} \mathrm{O}_{2}$, which corresponds to the organic peroxide mixing ratio. The catalase efficiency for channel $\mathrm{B}$ is determined from every liquid calibration cycle and was in the range of 90-98\% during both HOOVER missions.

During the field campaigns, calibrations with liquid $\mathrm{H}_{2} \mathrm{O}_{2}$ standards $\left(35.5 \mu \mathrm{g} \mathrm{l}^{-1}\right)$ were performed for both channels of the instrument before and after each flight. The actual liquid standards were produced by serial dilution from stock solution $\left(1.015 \times 10^{-2} \mathrm{M}\right)$. Gas phase calibrations of $\mathrm{H}_{2} \mathrm{O}_{2}$ were performed before each flight with a temperature controlled permeation source. A calibration gas is created from $30 \%$ $\mathrm{H}_{2} \mathrm{O}_{2}$ in a glass flask embedded in a temperature controlled oven at $40^{\circ} \mathrm{C}$. In-situ generated zero gas (Zero Air generator CAP 60, Infiltec, Germany) is flushed at a rate of 40 standard cubic centimeter $(\mathrm{sccm})$ per minute through a PET tubing going through a flask with a temperature dependent $\mathrm{H}_{2} \mathrm{O}_{2}$ atmosphere. A defined amount of $\mathrm{H}_{2} \mathrm{O}_{2}$ molecules permeates through the PET tubing's walls and the generated $\mathrm{H}_{2} \mathrm{O}_{2}$ gas standard can be diluted with extra zero air to the mixing ratios of $10.86 \pm 0.5 \mathrm{nmol} \mathrm{mol}^{-1}$ for HOOVER 1 and $4.8 \pm 0.2 \mathrm{nmol} \mathrm{mol}^{-1}$ for HOOVER 2 , respectively. The permeation source was calibrated by bubbling the gas through a water filled flask followed by titration of the resulting 

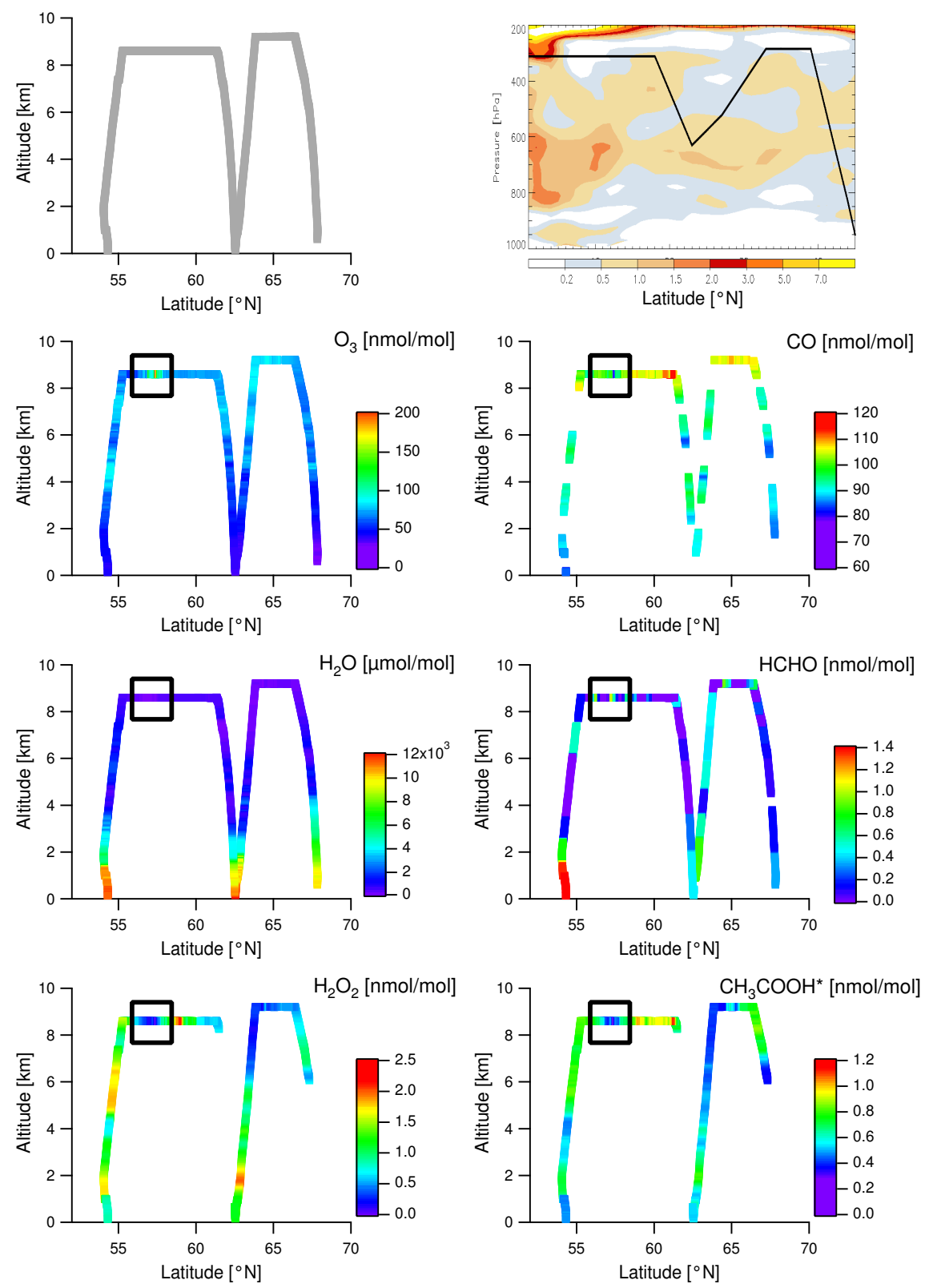

Fig. 2. Upper left corner: standard path of a HOOVER flight shown as altitude vs. latitude plot. Other figures show the mixing ratios of $\mathrm{H}_{2} \mathrm{O}_{2}, \mathrm{CH}_{3} \mathrm{OOH} * \mathrm{HCHO}, \mathrm{O}_{3}, \mathrm{CO}$ and $\mathrm{H}_{2} \mathrm{O}$ of HOOVER flight 10 as colour codes of the vertical profiles. The stratospheric influence during this flight can be seen in the black rectangle. Ozone values are $\gg 100 \mathrm{nmol} \mathrm{mol}^{-1}$ tend to be anticorrelated with CO. Both peroxides show very low values in this intrusion. Upper right corner: ECMWF simulated potential vorticity values for this flight as colour code with the flight track sketched only roughly as the black line (hence the deviation with the precise flight tracks in the other panels), providing supporting evidence for a stratospheric intrusion.

solution against a potassium permanganate solution or by UV spectroscopy after reaction with $\mathrm{TiCl}_{4}$ as described in Pilz and Johann (1974). A bypass (1/4" tubing containing two cartridges, IAH-432 filled with hopcalite type IAC-330 and IAH-434 filled with silica gel type IAC-502, Infiltec, Speyer, Germany) was used to generate peroxide free air for in-flight gas zeroing during the flights.
Due to the measuring technique we apply as described above, we cannot calculate a specific mixing ratio for MHP because all organic peroxides are measured. However, former studies show that the largest amount (90-100\% in the following cited studies) of the free tropospheric organic hydroperoxides consists of MHP (Heikes et al., 1996a; Jackson and Hewitt, 1996; Walker et al., 2006; Hua et al., 2008). So 
even though there is no proof that our signal is all MHP, we still think our data is valuable information to have, so we included the organic channel measurements by assuming it is made up completely by MHP. In order to clearly point out that we have not actually measured MHP specifically we call it MHP* or $\mathrm{CH}_{3} \mathrm{OOH} *$ throughout the manuscript. The organic peroxide data is hence upward corrected for the lower sampling efficiency of $\mathrm{CH}_{3} \mathrm{OOH}$ compared to the one for $\mathrm{H}_{2} \mathrm{O}_{2}$. Naturally, care has to be taken while interpreting the $\mathrm{CH}_{3} \mathrm{OOH} *$ data especially in the lower troposphere as other potentially abundant organic hydroperoxides can influence the results. Due to the fact that there are possibly other organic peroxides, MHP* is an upper limit for $\mathrm{CH}_{3} \mathrm{OOH}$.

The data have to be corrected for an existing $\mathrm{O}_{3}$ interference of the $\mathrm{H}_{2} \mathrm{O}_{2}$ measurements by subtraction of $6 \times 10^{-4}$ $\left(\mathrm{nmol} \mathrm{mol}^{-1}\right) /\left(\mathrm{nmol} \mathrm{mol}^{-1}\right) \times\left[\mathrm{O}_{3}\right]$ (Stickler et al., 2006). Since this interference is not only dependent on $\mathrm{O}_{3}$ but also on $\mathrm{H}_{2} \mathrm{O}$ mixing ratios, it cannot be completely linearly corrected. Hence, we assume an upper estimate for the systematic uncertainty of the $\mathrm{H}_{2} \mathrm{O}_{2}$ measurements of $+25 \%$ which has been derived from a measured value of this interference at $0.3 \mathrm{nmol} \mathrm{mol}^{-1} \mathrm{H}_{2} \mathrm{O}_{2}$ and $100 \mathrm{nmol} \mathrm{mol}^{-1} \mathrm{O}_{3}$ near the tropopause region. This is a conservative estimate and measurements throughout the rest of the troposphere have significantly smaller uncertainty due to the lower $\mathrm{O}_{3}$ abundance. A similar setup has been used and characterised by Stickler et al. $(2006,2007)$. The total uncertainties are determined as:

$\Delta_{1}=\sqrt{\left((P)^{2}+(\mathrm{US})^{2}+(\mathrm{IE})^{2}+(\mathrm{OC})^{2}\right)}$

with $P=$ Precision, US $=$ Uncertainty of the Standard, $\mathrm{IE}=\delta$ inlet efficiency and $\mathrm{OC}=\delta \mathrm{O}_{3}$ correction.. For the measurements and values during the campaigns uncertainties were calculated to be $\pm 12.3 \%$ at $0.26 \mathrm{nmol} \mathrm{mol}^{-1}$ (for HOOVER1, from here on simply H1) and $\pm 13.9 \%$ at $0.26 \mathrm{nmol} \mathrm{mol}^{-1}$ (for HOOVER2, from here on simply $\mathrm{H} 2$ ) for $\mathrm{H}_{2} \mathrm{O}_{2}$ and $\pm 20.6 \%$ at $0.18 \mathrm{nmol} \mathrm{mol}^{-1}$ (H1) and $\pm 20.9 \%$ at $0.22 \mathrm{nmol} \mathrm{mol}^{-1}$ (H2) for $\mathrm{CH}_{3} \mathrm{OOH} *$. The precision was determined as the 1 sigma variability of a $15 \mathrm{~min}$ period of in-flight ambient data measuring a homogeneous airmass at unperturbed background conditions. Values are $\pm 5.3 \%$ at $0.26 \mathrm{nmol} \mathrm{mol}^{-1}$ (H1) and $\pm 8.3 \%$ at $0.26 \mathrm{nmol} \mathrm{mol}^{-1}(\mathrm{H} 2)$ for $\mathrm{H}_{2} \mathrm{O}_{2}$ and $\pm 5.3 \%$ at $0.18 \mathrm{nmol} \mathrm{mol}^{-1}$ (H1) and $\pm 6.3 \%$ at $0.22 \mathrm{nmol} \mathrm{mol}^{-1}$ (H2) for $\mathrm{CH}_{3} \mathrm{OOH} *$. The detection limits (DL) were derived from the 1 sigma variability of a zero gas measurement over 20 min. Values are $26 \mathrm{pmol} \mathrm{mol}^{-1}$ (H1) and $24 \mathrm{pmol} \mathrm{mol}^{-1}$ (H2) for both $\mathrm{H}_{2} \mathrm{O}_{2}$ and $\mathrm{CH}_{3} \mathrm{OOH} *$.

\subsection{Measurements of $\mathrm{HCHO}, \mathrm{CO}$ and $\mathrm{CH}_{4}$}

$\mathrm{HCHO}, \mathrm{CO}$ and $\mathrm{CH}_{4}$ were measured with the TRacer In Situ Tdlas for Atmospheric Research (TRISTAR) multi channel infrared laser absorption spectrometer. The instrument has evolved from an originally tuneable diode laser based spectrometer, (hence the name) to a now quantum cascade (QC) laser based system. The three QC lasers (Alpes Laser, Lausanne, Switzerland) used in the instrument emit at 1268.98, 2158.30 , and 1759.72 centimeter $(\mathrm{cm})^{-1}$ and are used to measure $\mathrm{CH}_{4}, \mathrm{CO}$ and $\mathrm{HCHO}$, respectively. Each laser is coupled successively into the double corner cube White cell by pneumatically driven moveable mirrors. The cell alignment is set up to provide 128 passes throught the White cell resulting in a total pathlength of $64 \mathrm{~m}$. The White cell is evacuated to $45 \mathrm{hPa}$ in order to achieve narrower absorption lines. The whole optical system is actively temperature controlled to $(40 \pm 0.2)^{\circ} \mathrm{C}$ in order to minimise temperature related drifting of the spectrometer. The three lasers and two mercury cadmium telluride detectors are housed in a single liquid nitrogen dewar. Data aquisition is flexible and cycles and averaging times can be set for each species individually. The averaging was set to between 0.7 and $1.4 \mathrm{~s}$ for $\mathrm{CO}$ and $\mathrm{CH}_{4}$ and between 1.6 and $2 \mathrm{~s}$ for $\mathrm{HCHO}$ as the mixing ratio of the latter compound is very low in the UT, close to the detection limit of the instrument. Measurement cycles were $60 \%$ of the time for $\mathrm{HCHO}, 20 \%$ for $\mathrm{CH}_{4}$ and $20 \%$ for CO. Analysis software, developed within IGOR Pro (Wavemetrics, Portland, USA) was used for background subtraction, fitting to calibration spectra and determination of mixing ratios. The background could be subtracted either by time based linear interpolation or by curve fitting routines. For experimental data during the HOOVER measurements showing non-linear background changes, the latter process resulted in better detection limits. Calibrations for HCHO were performed with a HCHO permeation source (sealed wafer device from Valco Instruments Co. Inc. in glass tube controlled to $70^{\circ} \mathrm{C}$ ) before and after each flight. The permeation source was flushed permanently with $30 \mathrm{sccm}$ per minute and mixing ratios were adjusted to $5-8 \mathrm{nmol} \mathrm{mol}^{-1}$ with additional zero air. The detection limits of the HCHO measurements were determined as the 1 sigma variability of the background measurements during HOOVER and were $0.15 \mathrm{nmol} \mathrm{mol}^{-1}$ at $120 \mathrm{~s}$ averages $(\mathrm{H} 1)$ and $0.032 \mathrm{nmol} \mathrm{mol}^{-1}$ at $120 \mathrm{~s}$ averages (H2). The total uncertainty of the measurements was determined as $\Delta_{2}=\sqrt{\left((P)^{2}+(\mathrm{US})\right)^{2}}$.

The 1-sigma total uncertainty values were calculated to be $1.10 \%$ for $\mathrm{CO}, 0.57 \%$ for $\mathrm{CH}_{4}$ and $8.56 \%$ for $\mathrm{HCHO}$. We refer to Schiller et al. (2008) for more details on the different methods that were used to calculate the DL for TRISTAR and for an in depth description of the instrument and its performance during HOOVER.

\subsection{Other species}

$\mathrm{NO}$ and $\mathrm{O}_{3}$ measurements were performed with a chemiluminescence detector (ECO PHYSICS SR790H, Munich, Germany). The total uncertainty was determined as $\pm\left(7.5 \mathrm{pmol} \mathrm{mol}^{-1}, 6.6 \%\right)$ of the measured value for $\mathrm{NO}$ and $\pm\left(0.94 \mathrm{nmol} \mathrm{mol}^{-1}, 4 \%\right)$ of the measured value for $\mathrm{O}_{3}$ with a time resolution of $1 \mathrm{~s}$. $J_{\mathrm{NO}_{2}}$ data were recorded with a set of two filter radiometers (Meteorologie-Consult, Glashuetten, 
Germany), one facing upward, the other one downward. Precision of the $J_{\mathrm{NO}_{2}}$ data was determined to be $1 \%$ and the total uncertainty $15 \%$. OH was measured by means of laser induced fluorescence (LIF) spectroscopy. $\mathrm{HO}_{2}$ was measured indirectly after conversion to $\mathrm{OH}$ by addition of NO. The instrumental setup has already been used in a similar configuration during the GABRIEL campaign and is described in detail in Martinez et al. (2010). The precision of the LIF instrument during HOOVER was determined to be $7 \%$ for $\mathrm{OH}$ and $1 \%$ for $\mathrm{HO}_{2}$ with a detection limit of $0.02 \mathrm{pmol} \mathrm{mol}^{-1}$ for $\mathrm{OH}$ and $0.08 \mathrm{pmol} \mathrm{mol}^{-1}$ for $\mathrm{HO}_{2} \cdot \mathrm{H}_{2} \mathrm{O}$ was measured with a Helten Sensor (Humidata, Linnich-Tetz, Germany). Flight data (latitude, longitude, altitude, drift angle, wind direction, aircraft heading, wind speed, cabin temperature, true air speed) was provided from the enviscope data aquisition system (enviscope GmbH, Frankfurt, Germany).

\subsection{The atmospheric chemistry models EMAC and MATCH-MPIC}

In this study we compare our HOOVER in-situ measurements to simulations from the two global 3-D models, the "Model of Atmospheric Transport and CHemistry - Max Planck Institute for Chemistry version 3.0" (MATCH-MPIC) and the "ECHAM/MESSy Atmospheric Chemistry (EMAC) model". In order to have comparable datasets for in-situ measurements and model data, virtual fly-throughs along the GPS recorded flight tracks were performed through the 4-D datasets available from both models. So for each datapoint in the measurements a data point in the time- and spacewise interpolated model field was picked and placed on the respective timegrid of the flight. From here on measurements and simulations were processed in the same manner.

\subsubsection{EMAC}

The ECHAM/MESSy Atmospheric Chemistry (EMAC) model is a numerical chemistry and climate simulation system that includes sub-models describing tropospheric and middle atmosphere processes and their interaction with oceans, land and human influences (Jöckel et al., 2006). It uses the Modular Earth Submodel System (MESSy; Jöckel et al., 2005) to link multi-institutional computer codes. The core atmospheric model is the 5th generation European Centre Hamburg general circulation model (ECHAM5, Roeckner et al., 2006). For the present study we applied EMAC in the T42L90MA-resolution, i.e. with a spherical truncation of T42 (corresponding to a quadratic gaussian grid of approx. 2.8 by 2.8 degrees in latitude and longitude) with 90 vertical hybrid pressure levels up to $0.01 \mathrm{hPa}$. Model output for further analysis was triggered every $5 \mathrm{~h}$ simulation time.

For the present study, the prognostic variables vorticity, divergence, temperature and the (logarithm of the) surface pressure have been nudged to the operational ECMWF analysis data in order to allow a point-to-point compari- son to our observations (see Jöckel et al. (2006) for further details). Stratospheric and tropospheric gas-phase and heterogeneous chemistry was calculated with the submodel MECCA (Module Efficiently Calculating the Chemistry of the Atmosphere, Sander et al., 2005), aqueous-phase chemistry in cloud droplets and wet scavenging with the submodel SCAV (Tost et al., 2006). Primary emissions and dry deposition of trace gases and aerosols were calculated with the submodels ONLEM, OFFLEM, TNUDGE (Kerkweg et al., 2006b) and DRYDEP (Kerkweg et al., 2006a), respectively. More details on the overall model setup are presented by Jöckel et al. (2010).

\subsubsection{MATCH-MPIC}

MATCH-MPIC is a chemistry transport model (CTM) that is run in "offline" mode, driven by meteorological data from the National Centre for Environmental Prediction Global Forecast System (NCEP GFS). The model contains an extensive nonmethane hydrocarbon (NMHC) oxidation chemistry described in detail by von Kuhlmann et al. (2003) and is optimised for the troposphere. MATCH does not contain stratospheric chemistry; instead, this is parameterised by using stratospheric observations from the HALOE project (von Kuhlmann et al., 2003) to prescribe the zonal mean mixing ratios of several compounds $\left(\mathrm{H}_{2} \mathrm{O}, \mathrm{O}_{3}\right.$, reactive nitrogen compounds and $\mathrm{CH}_{4}$ ) in all layers more than about $30 \mathrm{hPa}$ above the tropopause. For the dataset used in this study the model was also run at a horizontal resolution of T42 (about $2.8^{\circ} \times 2.8^{\circ}$ ) and with a vertical resolution of 42 levels up to $2 \mathrm{hPa}$. The temporal resolution of the output from MATCH was $3 \mathrm{~h}$. A detailed model description of MATCH-MPIC can be found in Lawrence et al. (2003).

\subsection{The CAABA box model}

The Chemistry As A Boxmodel Application (CAABA) (Sander et al., 2011) is an atmospheric chemistry box model developed within the MESSy framework (Jöckel et al., 2005). In this study, CAABA version 2.6 is used as base model with the submodels MECCA for atmospheric chemistry and JVAL for photolysis rate coefficients (J-values) coupled via the standardised MESSy interface. The model is initialised with mean values from observations for the respective tropospheric region of the HOOVER 2 campaign. Peroxides are not initialised and start from zero. J-values are calculated with the Tropospheric Ultraviolet and Visible (TUV) model from measured $J_{\mathrm{NO}_{2}}$ values similar to Stickler et al. (2006). All missing species are calculated for the specific time and postion from the model. Deposition and emission processes are deactivated for our calculations as well as liquid phase chemistry in order to get an all gas phase photochemical simulation for comparison with EMAC. 

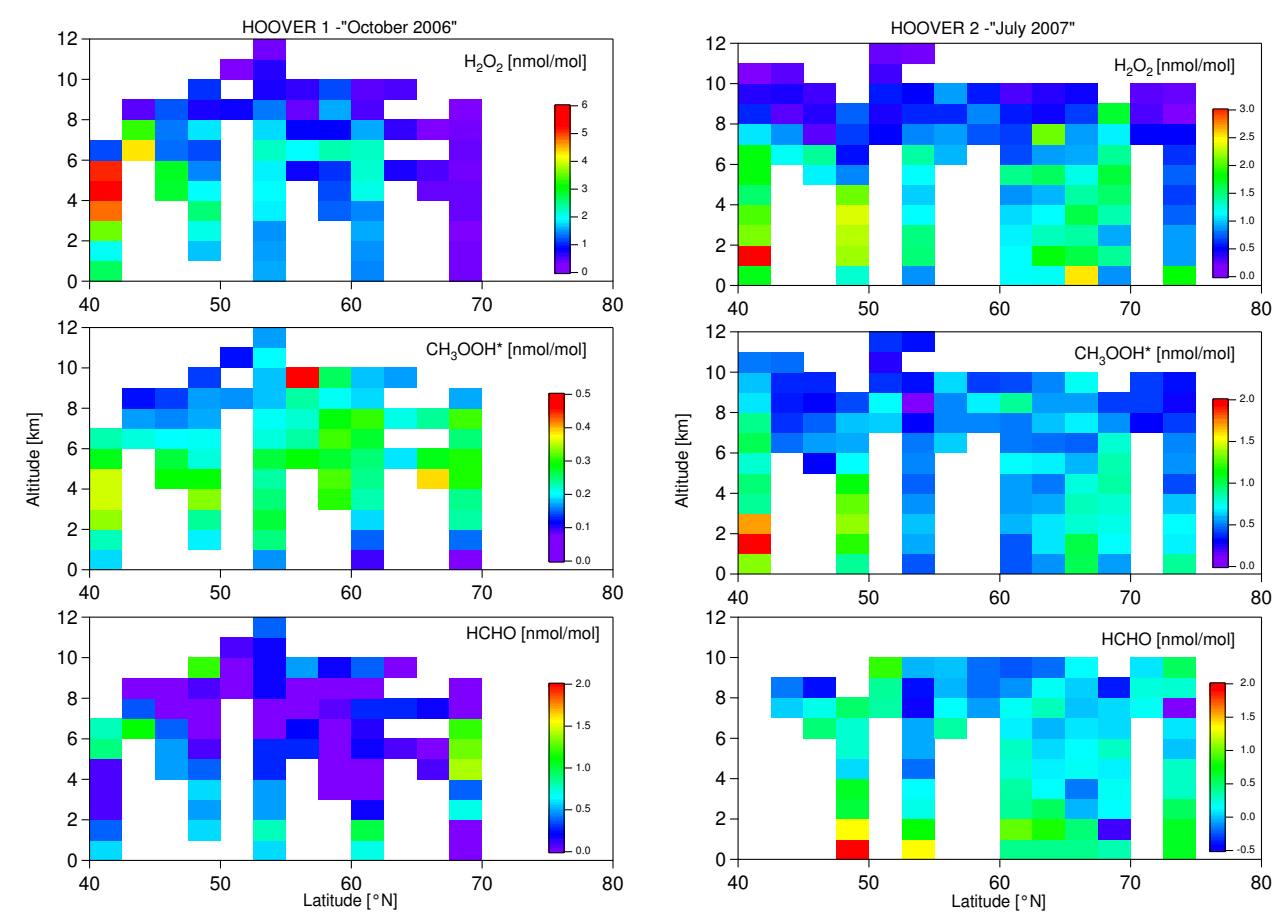

Fig. 3. Data maps for the HOOVER 1 (left) and HOOVER 2 (right) campaigns. Boxes define data subsets over $2.5^{\circ}$ latitude sections and a height of $1 \mathrm{~km}$. The colour code depicts median mixing ratios of each box in nmol mol${ }^{-1}$.

\section{Results and discussion}

\subsection{Spatial distribution of $\mathrm{H}_{2} \mathrm{O}_{2}, \mathrm{CH}_{3} \mathrm{OOH} *$ and HCHO during HOOVER}

During HOOVER we measured $\mathrm{H}_{2} \mathrm{O}_{2}$ mixing ratios in a wide range from the DL $\left(25 \mathrm{pmol} \mathrm{mol}^{-1}\right)$ up to $5.5 \mathrm{nmol} \mathrm{mol}^{-1}$. The geographic distribution of $\mathrm{H}_{2} \mathrm{O}_{2}$ during the autumn and summer campaigns is shown as a function of latitude and altitude in Fig. 3. The median values of the data are binned into subsets of $2.5^{\circ} \times 1 \mathrm{~km}$ (latitude $\times$ altitude) for all flights in this region of the specified field campaign. There are only small differences between the two seasons in terms of absolute mixing ratios. For the $\mathrm{H} 2$ summer campaign, typical $\mathrm{H}_{2} \mathrm{O}_{2}$ altitude profiles show maximum mixing ratios in a region above the boundary layer at an altitude of $2-5 \mathrm{~km}$. A negative gradient of mixing ratios with increasing latitude is observed for $\mathrm{H}_{2} \mathrm{O}_{2}$ at all height levels. In general, the summer shows weaker latitudinal gradients compared to autumn. Surprisingly, slightly higher mixing ratios of $\mathrm{H}_{2} \mathrm{O}_{2}$ were measured in autumn than in summer in the mid troposphere (MT) over the Mediterranean at $40^{\circ}$ to $50^{\circ} \mathrm{N}$. As $\mathrm{H}_{2} \mathrm{O}_{2}$ formation is related to sunlight intensity, we expected higher abundances in the summer compared to autumn. In the study by Snow et al. (2007) a strong seasonal variation in $\mathrm{H}_{2} \mathrm{O}_{2}$ mixing ratios was observed over North America and the North Atlantic with up to one order of magnitude higher mixing ratios in summer than autumn/winter-spring. We do not find such similar variations over Europe for HOOVER. Although the measurements are only a snapshot at a certain time a comparison with the UTOPIHAN data (see Fig. 5) indicates that seasonal variations are more in the order of a factor of 2-3 instead of an order of magnitude. A possible explanation could be higher cloud scavenging of soluble $\mathrm{H}_{2} \mathrm{O}_{2}$ during the summer seasons due to enhanced convective activity.

$\mathrm{CH}_{3} \mathrm{OOH} *$ mixing ratios during autumn ranged from the DL $\left(25 \mathrm{pmol} \mathrm{mol}^{-1}\right)$ up to $2.6 \mathrm{nmol} \mathrm{mol}^{-1}$. There is an increase of mixing ratios from the autumn to the summer by a factor of 2.7 on average, which is in line with enhanced photochemical production due to stronger solar radiation. Altitude profiles of $\mathrm{CH}_{3} \mathrm{OOH} *$ have a similar shape to those of $\mathrm{H}_{2} \mathrm{O}_{2}$, although being flatter overall. A distinct maximum above the boundary layer of $\mathrm{CH}_{3} \mathrm{OOH} *$ mixing ratios can be found at all latitudes over Europe. Significant latitudinal trends for the species are only found during the summer campaign, whereas $\mathrm{CH}_{3} \mathrm{OOH} *$ was found to be relatively homogeneously distributed in autumn. The strongest gradients in the summer are found in the lower and middle troposphere, while there are no clear gradients in the UT. Analogous to $\mathrm{H}_{2} \mathrm{O}_{2}$, elevated mixing ratios were encountered over the Mediterranean region, especially in summer, while at higher latitudes $\mathrm{CH}_{3} \mathrm{OOH}$ is rather homogeneously distributed in the MT and the UT. 
$\mathrm{HCHO}$ mixing ratios during autumn were in the range of the DL ( $32 \mathrm{pmol} \mathrm{mol}^{-1}$ ) up to $1.2 \mathrm{nmol} \mathrm{mol}^{-1}$. The mixing ratios are of similar magnitude in both seasons, with the exception of the Mediterranean region, where strongly elevated levels of HCHO were measured in summer compared to the other latitudinal subregions. The altitude profiles of $\mathrm{HCHO}$ are similar in both seasons. The highest mixing ratios were measured close to the ground and from here on levels generally drop steeply with altitude, being close to the DL from $\approx 6 \mathrm{~km}$ upwards. However, there are some regions with maxima in the mid troposphere and increasing HCHO mixing ratios in the UT. On several occasions elevated levels of HCHO were observed in the UT, in general associated with enhanced NO mixing ratios (see Fig. 4) indicating enhanced photochemical production in polluted air (Stickler et al., 2006). Additionally, enhanced levels of $\mathrm{HCHO}$ are found over the Mediterranean, which again features the highest abundance consistent with former studies that find high mixing ratios of HCHO throughout the troposphere over the Mediterranean (Lelieveld et al., 2002). Overall, the seasonal difference of $\mathrm{HCHO}$ is relatively small between $\mathrm{H} 1$ and $\mathrm{H} 2$ compared to the peroxides.

\subsection{Comparison of HOOVER to former field studies}

In the framework of the UTOPIHAN-ACT project a series of measurement campaigns was performed in 2002-2004 over Europe (Stickler et al., 2006; Colomb et al., 2006). Since the UTOPIHAN-ACT flight tracks cover a similar latitudinal range, they are displayed together with those from HOOVER in Fig. 1. However, during UTOPIHAN-ACT the focus of research was sampling UT air and therefore less data were collected in the BL and MT. Especially UTOPIHAN-ACT 2 and HOOVER 2 are interesting for a direct comparison, since both missions were carried out in summer.

$\mathrm{H}_{2} \mathrm{O}_{2}$ medians (mean \pm 1 sigma) from all latitudes during UTOPIHAN-ACT 2 in nmol mol-1 were:

\section{UTOPIHAN-ACT 2 HOOVER 2}

\begin{tabular}{lll}
\hline UT & $0.50(0.50 \pm 0.35)$ & $0.56(0.68 \pm 0.44)$ \\
FT & $1.77(1.77 \pm 1.00)$ & $1.40(1.52 \pm 0.73)$ \\
BL & $1.31(1.72 \pm 1.34)$ & $1.60(1.74 \pm 0.75)$
\end{tabular}

$\mathrm{CH}_{3} \mathrm{OOH} *$ medians observed during UTOPIHAN-ACT 2 in $\mathrm{nmol} \mathrm{mol}^{-1}$ were:

\begin{tabular}{ccc} 
& UTOPIHAN-ACT 2 & HOOVER 2 \\
\hline UT & $0.35(0.36 \pm 0.14)$ & $0.49(0.52 \pm 0.19)$ \\
FT & $0.65(0.63 \pm 0.27)$ & $0.72(0.78 \pm 0.34)$ \\
BL & $0.56(0.55 \pm 0.37)$ & $0.85(0.92 \pm 0.47)$
\end{tabular}

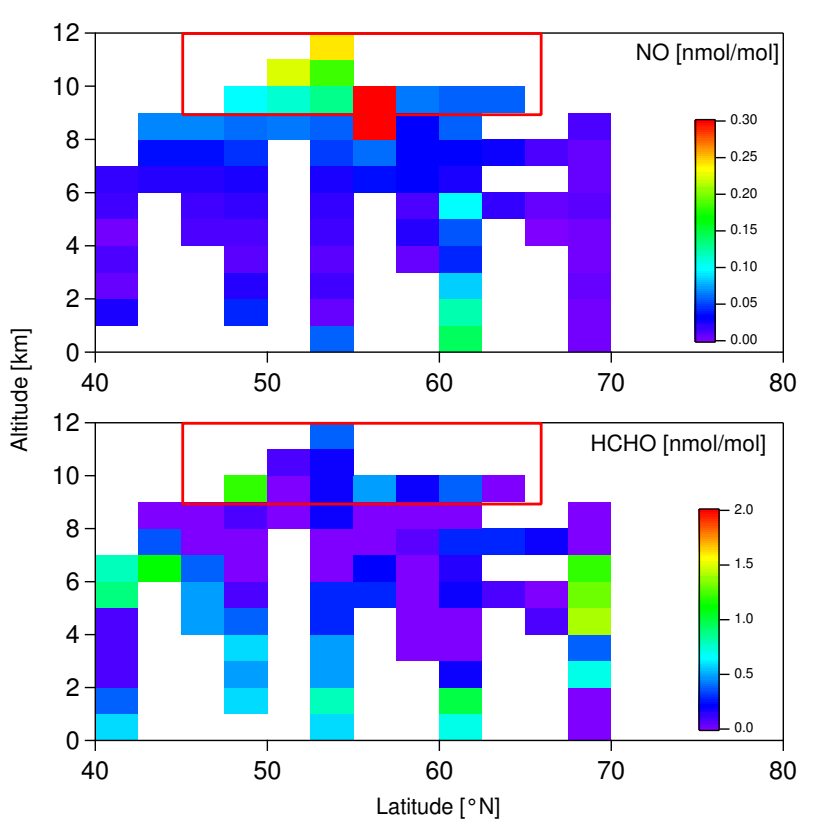

Fig. 4. Data maps for NO and HCHO during HOOVER 1 in October 2006. The red frame shows a positive correlation of $\mathrm{NO}$ with $\mathrm{HCHO}$ in the upper troposphere.

Overall, the median mixing ratios for both summer campaigns show deviations in the $10-30 \%$ range for the peroxides. In comparison to the summer campaigns, we find a factor of 2-3 lower mixing ratios for the peroxides during UTOPIHAN 3, which was carried out in late winter. This is expected due to a reduced photochemical activity in this season. HCHO medians observed during UTOPIHAN-ACT 2 were:

\begin{tabular}{ccc} 
& UTOPIHAN-ACT 2 & HOOVER 2 \\
\hline UT & $0.24(0.33 \pm 0.34)$ & $0.02(0.03 \pm 0.46)$ \\
FT & $0.34(0.52 \pm 0.58)$ & $0.20(0.20 \pm 0.38)$ \\
BL & $1.79(1.69 \pm 0.90)$ & $0.73(0.83 \pm 0.72)$
\end{tabular}

In general, deviations for $\mathrm{HCHO}$ between both summer missions are larger than for the peroxides. HCHO during UTOPIHAN 3 (winter) is a factor of 4 lower in the MT than in summer but surprisingly almost twice as high in the UT.

Over North America a series of airborne measurement campaigns was carried out between 1997 and 2004: the Subsonic Assessment of Ozone and Nitrogen (SONEX, autumn 1997), the Tropospheric Ozone Production about the Spring Equinox (TOPSE, winter-spring 2000) and the NASA Intercontinental Transport Experiment - North America (INTEXNA, summer 2004) campaigns covered a similar latitude range as the HOOVER and UTOPIHAN-ACT campaigns. The ROOH and HCHO measurements of these studies have been summarised by Snow et al. (2007). The similarity 

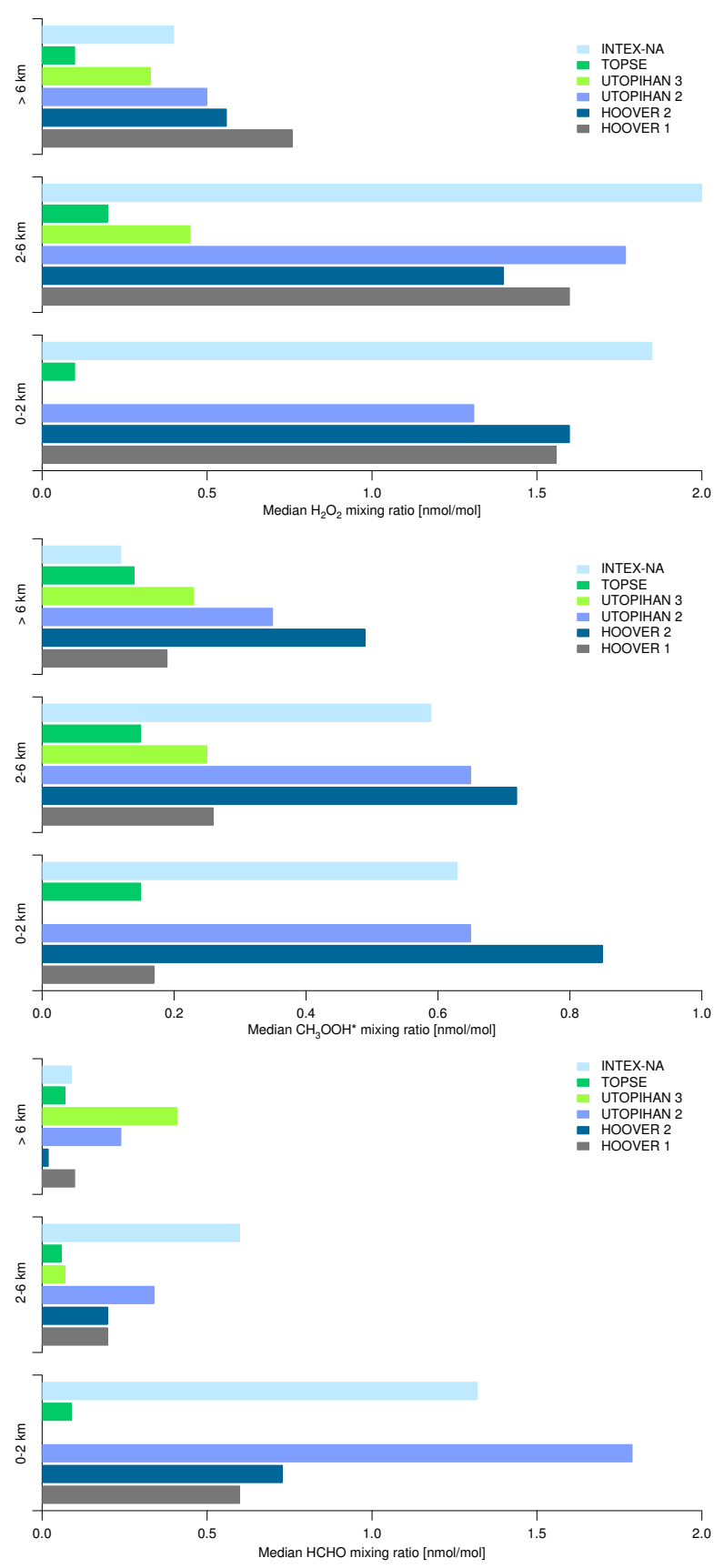

Fig. 5. Comparison of the TOPSE (March/April 2000), INTEXNA (July 2004), UTOPIHAN 2 (July 2003), UTOPIHAN 3 (March 2004), HOOVER 1 (October 2006) and HOOVER 2 (July 2007) measurement campaigns. The median values for the respective altitude regions are shown as bars for $\mathrm{H}_{2} \mathrm{O}_{2}, \mathrm{CH}_{3} \mathrm{OOH} *$ and $\mathrm{HCHO}$.

of these measurements makes them suitable for comparison with the results of this study. Moreover, the study from Snow et al. (2007) so far represents a unique dataset for the spatial distribution of these species throughout the whole range of the troposphere. The INTEX-NA and HOOVER 2 campaigns were both carried out over continental regions and during summer months and are thus particulary interesting for comparison.

The $\mathrm{H}_{2} \mathrm{O}_{2}$ mixing ratios from the DL $\left(25 \mathrm{pmol} \mathrm{mol}^{-1}\right)$ up to $5.5 \mathrm{nmol} \mathrm{mol}^{-1}$ observed during HOOVER are comparable to previous studies that also show a range of the values of up to an order of magnitude (Balasubramanian and Husain, 1997; Weinstein-Lloyd et al., 1998; Hua et al., 2008). During INTEX-NA maximum values reached up to $13 \mathrm{nmol} \mathrm{mol}^{-1}$, but similar median values were measured as shown later on. In contrast to the North American campaigns, a rather small seasonal cycle in mixing ratios between summer and winter/spring was observed during HOOVER and UTOPIHAN-ACT, with a difference of a factor of 2 between the UTOPIHAN-ACT summer and spring campaigns (Fig. 5, upper panel). In contrast, there is up to a factor of 10 difference between the SONEX/TOPSE (winter/spring) and INTEX-NA (summer) measurements. However, one has to be careful when comparing these seasonal variations, since the SONEX mission was not exactly in the same area as the INTEX-NA campaign and the flights were to a large extent made in the marine environment over the Atlantic Ocean. Nevertheless, during TOPSE mixing ratios were much lower than during the UTOPIHAN-ACT 3 (winter/spring) mission although both took place during the winter-spring transition. One has to keep in mind that these measurements provide snapshots, and thus discrepancies could also be due to different synoptic conditions. However, the observations seem to indicate a larger seasonal variability over North America than over Europe. It is noteworthy that the median mixing ratios measured during HOOVER and UTOPIHANACT are both comparable to those in INTEX-NA, which are already amongst the highest mixing ratios measured over North America. Still higher values have been observed in cases where Asian or Brazillian outflow was observed (Heikes et al., 1996b,a; O'Sullivan et al., 2004; Snow et al., 2007). In general, the absolute mixing ratios and altitude distribution of $\mathrm{H}_{2} \mathrm{O}_{2}$ observed during HOOVER 2 are in good agreement with INTEX-NA observations, also carried out in the summer months. $\mathrm{CH}_{3} \mathrm{OOH} *$ mixing ratios during HOOVER ranged from the DL $\left(25 \mathrm{pmol} \mathrm{mol}^{-1}\right)$ up to $2.6 \mathrm{nmol} \mathrm{mol}^{-1}$, which is in agreement with measurements from INTEX-NA (up to $2.1 \mathrm{nmol} \mathrm{mol}^{-1}$ ). $\mathrm{CH}_{3} \mathrm{OOH} *$ shows a distinct seasonal cycle during HOOVER with mixing ratios in summer (H2) being a factor of $2.5(\mathrm{UT})-5(\mathrm{BL})$ higher than in autumn (H1) (Fig. 5, middle panel). This difference is similar to that between INTEX-NA (summer) and TOPSE (spring) 1.2 (UT) - 4.5 (BL) except for the UT where no significant variation between TOPSE and INTEXNA was found. The situation looks different for the UT where TOPSE and INTEX-NA show almost the same mixing ratios, while we observe an increase of a factor of 2-3 from autumn (H1) to summer ( $\mathrm{H} 2)$. $\mathrm{CH}_{3} \mathrm{OOH}$ measured during INTEX-NA was lower than HOOVER 2 by a factor of $\approx 1.3$ 
$(0-2 \mathrm{~km}), 1.2(2-6 \mathrm{~km})$ and $4(>6 \mathrm{~km})$ but shows similar altitude profiles during both INTEX-NA and HOOVER. Observed latitudinal distributions for both campaigns are qualitatively similar. HCHO mixing ratios during HOOVER ranged from the DL ( $32 \mathrm{pmol} \mathrm{mol}^{-1}$ ) up to $1.2 \mathrm{nmol} \mathrm{mol}^{-1}$, which contrasts with a range of about $4 \mathrm{nmol} \mathrm{mol}^{-1}$ observed during INTEX-NA. The seasonal variation of HCHO during HOOVER is rather small, with median values being only slightly higher in summer compared to autumn, especially over the Mediterranean area. We find an increase of a factor $1.2(0-2 \mathrm{~km}), \approx 1(2-6 \mathrm{~km})$ and a decrease of a factor $5(>6 \mathrm{~km})$ from $\mathrm{H} 1$ to $\mathrm{H} 2$ (Fig. 5 , lower panel). The strong relative deviation in the upper troposphere is likely due to the very low mixing ratios near the detection limit of the instrument in this region. In contrast, the values of INTEX-NA (summer) and TOPSE (spring) differ up to a factor of 10 in the BL and in the MT. Overall, the $\mathrm{H} 2$ mixing ratios with medians of $0.72 \mathrm{nmol} \mathrm{mol}^{-1}$ (BL), $0.20 \mathrm{nmol} \mathrm{mol}^{-1}$ (FT), $0.02 \mathrm{nmol} \mathrm{mol}^{-1}$ (UT)) are approximately a factor of two lower than those in INTEX-NA with medians of $1.3 \mathrm{nmol} \mathrm{mol}^{-1}$ (BL), 0.6 (FT) and 0.1 (UT). Altitude profiles for both campaigns are similar, with a strong decrease above the boundary layer.

\subsection{Comparison of in-situ measurements and 3-D model simulations}

In order to test our understanding of tropospheric chemistry, a comparison of in-situ data with output of the two global 3D models EMAC and MATCH-MPIC was performed. While the in-situ data are at rather high time resolution of the order of seconds to minutes, the time resolution of the model output data is $3 \mathrm{~h}$ for MATCH-MPIC and $5 \mathrm{~h}$ for EMAC. This poses the question, whether the difference in time resolution will affect the intercomparison. Therefore, in the EMAC simulations, data has been sampled along the flight path with the highest possible time resolution, i.e. with the model time step of 12 min (for details see Jöckel et al., 2010). The results were compared to the standard off-line virtual flights based on the 5 hourly model output. The difference between the two model simulation output frequencies was insignificant for the species discussed here. The spatial resolution of the models $\left(2.8^{\circ} \times 2.8^{\circ}\right.$ horizontal (both models) and 42 levels up to $2 \mathrm{hPA}$ (MATCH)/90 levels up to $0.01 \mathrm{hPA}$ (EMAC) vertical resolution) is also relatively coarse compared to the horizontal resolution of a few kilometers for the in-situ data. However, the models should be able to simulate vertical and large scale geographical trends, being the main focus of this study, while local discrepancies should not be overinterpreted. The comparisons of measurements and model calculations for both HOOVER campaigns are shown in Figs. 6 (altitude profiles), Figs. 7 and 8 (latitude profiles).

Both model calculations for $\mathrm{H}_{2} \mathrm{O}_{2}$ look relatively similar, especially for $\mathrm{H} 1$. Yet, both models deviate strongly from the measurements. Observed vertical gradients of $\mathrm{H}_{2} \mathrm{O}_{2}$ in
$\mathrm{H} 1$ are strongest in the $\mathrm{BL}$ and $\mathrm{MT}$ and less pronounced in the UT. The model simulations mostly reproduce these vertical profiles qualitatively, but underestimate absolute mixing ratios substantially by a factor of 3.3 (EMAC) and 7.5 (MATCH) on average. Additionally, the models do not reproduce the distinct maxima above the BL which are present in the observations. The observed latitudinal gradients during summer (H2) are weaker than those for H1. However, $\mathrm{H}_{2} \mathrm{O}_{2}$ still exhibits a pronounced latitudinal gradient at the top of the BL, that becomes smaller in the MT and nonsignificant in the UT. Contrary to the autumn mission (H1), the models reproduce tropospheric maxima of $\mathrm{H}_{2} \mathrm{O}_{2}$ at the top of the BL in summer with the EMAC model being closer to the measurements. For the summer $(\mathrm{H} 2)$ the models overall show a better agreement with the in-situ data, but are still off by a factor of 1.4 (EMAC) and 2.0 (MATCH-MPIC). In general, the EMAC simulation produces higher mixing ratios than MATCH-MPIC and is thus most of the time closer to the measurements. The situation is different for $\mathrm{CH}_{3} \mathrm{OOH} *$. In general, the observed latitudinal gradients for $\mathrm{CH}_{3} \mathrm{OOH}$ during $\mathrm{H} 1$ are weaker than for $\mathrm{H}_{2} \mathrm{O}_{2}$. A significant latitudinal gradient is only found in the boundary layer, while all other height levels do not show distinct gradients and only modest enhancements over the Mediterranean. Both models reproduce $\mathrm{CH}_{3} \mathrm{OOH} *$ quite well for the autumn campaign (H1), with MATCH performing better on average. Simulated mixing ratios are off by a factor of 1.5 (EMAC) and 1.1 (MATCH), with EMAC being too high and MATCH too low. The vertical profiles of $\mathrm{CH}_{3} \mathrm{OOH} *$ show a maximum above the BL over Southern Europe and relatively flat profiles over central and northern Europe, gradients that are well captured by both models. The picture changes considerably for the summer campaign (H2). Observed $\mathrm{CH}_{3} \mathrm{OOH} *$ exhibits a strong latitudinal gradient in the $\mathrm{BL}$ in summer, with very high mixing ratios above southern Europe, while over central and northern Europe similar, much lower values are measured. In contrast to the situation for autumn (H1), the simulations for summer (H2) are less satisfactory, with both models underestimating the observed mixing ratios by a factor of 2.4 (EMAC) and 3.3 (MATCH), respectively. Especially in the UT both models underestimate the $\mathrm{CH}_{3} \mathrm{OOH} *$ mixing ratio by a factor of 10 . For $\mathrm{H}_{2} \mathrm{O}_{2}$, the situation is the opposite, the models simulate the summer values better and show large deviations in the autumn. Vertical profiles of $\mathrm{CH}_{3} \mathrm{OOH}$ * show a summer maximum over the BL over southern Europe and relatively flat profiles over central and northern Europe, that are qualitatively reproduced by the models.

Generally, both models reproduce the absolute mixing ratios and the spatial distribution of HCHO remarkably well for both, autumn and summer HOOVER campaigns. There is a sharp decrease of HCHO from the maximum at ground level, reaching mixing ratios near the detection limit of the instrument at $4-8 \mathrm{~km}$, which is well reproduced by the models. The seasonal variation of $\mathrm{HCHO}$ with a decrease from summer to 


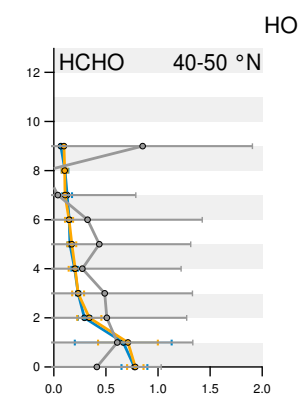

HOOVER 1 - October 2006
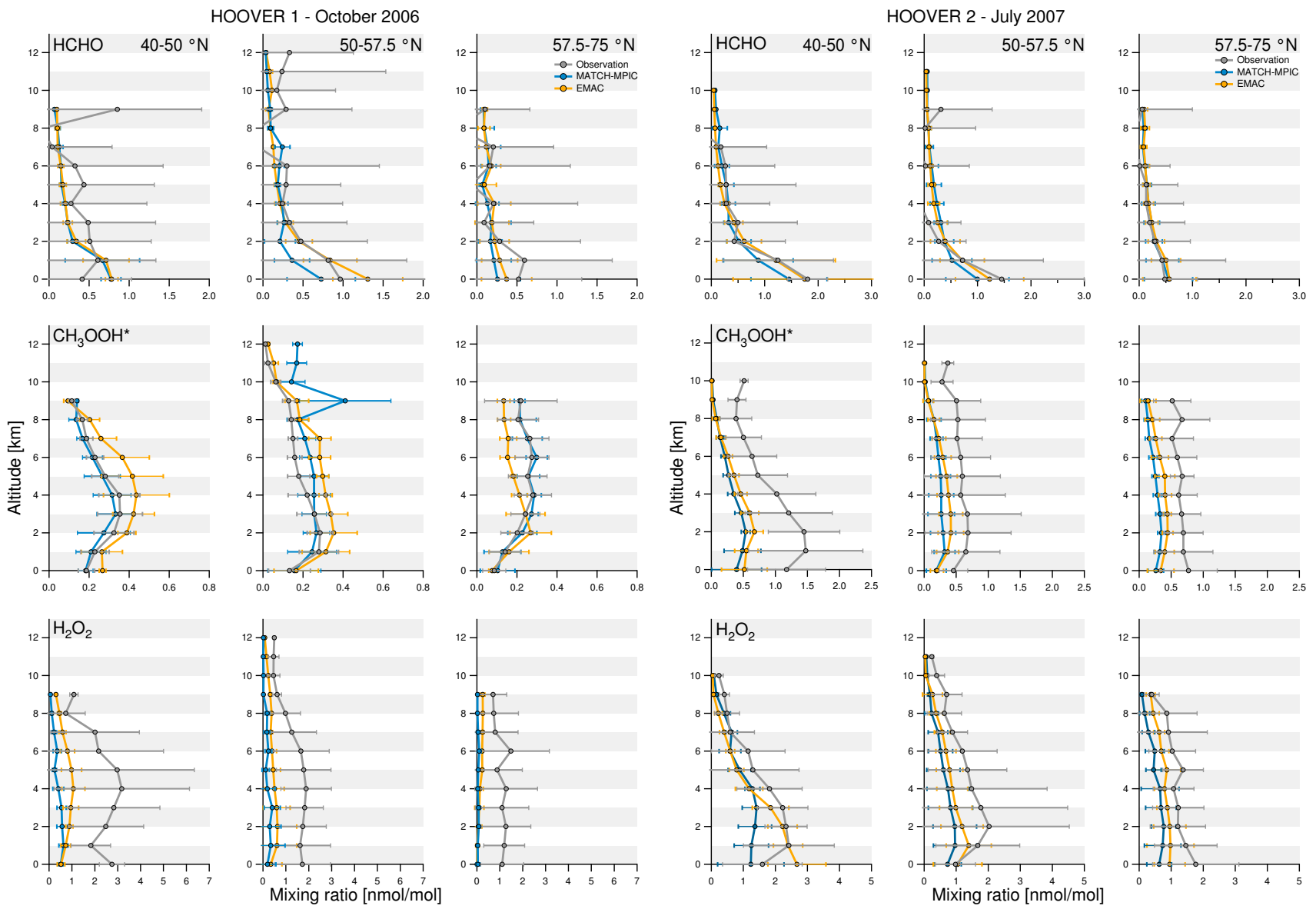

Fig. 6. Vertical profiles of $\mathrm{H}_{2} \mathrm{O}_{2}, \mathrm{CH}_{3} \mathrm{OOH} *$ and $\mathrm{HCHO}$ from HOOVER 1 (left panels) and HOOVER 2 (right panels). The data is subdivided into 3 latitude ranges: $40-50^{\circ} \mathrm{N}, 50-57.5^{\circ} \mathrm{N}, 57.5-75^{\circ}$, representing southern, central and northern Europe. The median values of in-situ measurements (grey), EMAC simulations (orange) and MATCH-MPIC simulations (blue) are plotted for $1 \mathrm{~km}$ steps together with 2 sigma as error bars.

autumn is also captured well by both models. However, none of the models shows an increase of $\mathrm{HCHO}$ mixing ratios for the UT, which is found in some of the measured vertical profiles.

\subsubsection{Sensitivity study: impact of cloud scavenging on the budget of $\mathrm{H}_{2} \mathrm{O}_{2}$ in the EMAC model}

Both models substantially underestimate the mixing ratio of $\mathrm{H}_{2} \mathrm{O}_{2}$ in the autumn (H1) campaign. Here we discuss potential causes for the measurement-model discrepancies. The formation of gaseous atmospheric $\mathrm{H}_{2} \mathrm{O}_{2}$ is strongly dependent on the $\mathrm{HO}_{2}$ radical as its main precursor. Figure 9 shows that the EMAC model simulation of the $\mathrm{HO}_{2}$ radicals is closer to the observations than the simulation of $\mathrm{H}_{2} \mathrm{O}_{2}$. This points to a possible overestimation of the $\mathrm{H}_{2} \mathrm{O}_{2}$ sinks in the EMAC model. Due to the high solubility of hydroperoxides, the effect of cloud and precipitation scavenging is a particularly important sink for the species (see Tost et al.,
2007). In general, scavenging has to be parameterised in the models, leading to substantial uncertainties concerning the quantitative impact of rainout on the budget of soluble species. The retention factor for example, which determines how much dissolved substance remains in a hydrometeor during freezing, is in the range of $5 \%$ to $100 \%$ for $\mathrm{H}_{2} \mathrm{O}_{2}$ (Iribarne and Pyshnov, 1990; Snider et al., 1992; Conklin et al., 1993; Snider and Huang, 1998). Part of this uncertainty is because the amount of $\mathrm{H}_{2} \mathrm{O}_{2}$ remaining in the cloud particles is dependent on the microphysics involved in the freezing process. These processes are complex and have not been simulated satisfactorily by models thus far (Stuart and Jacobson, 2003, 2004; Salzmann et al., 2007). Even highly soluble species have been reported to be transported to the UT effectively when assuming that they are outgassing during cloud droplet freezing (Barth et al., 2001a, 2007; Yin et al., 2002). It has been shown that these uncertainties, and in general the treatment of scavenging and transport in glaciated convective 

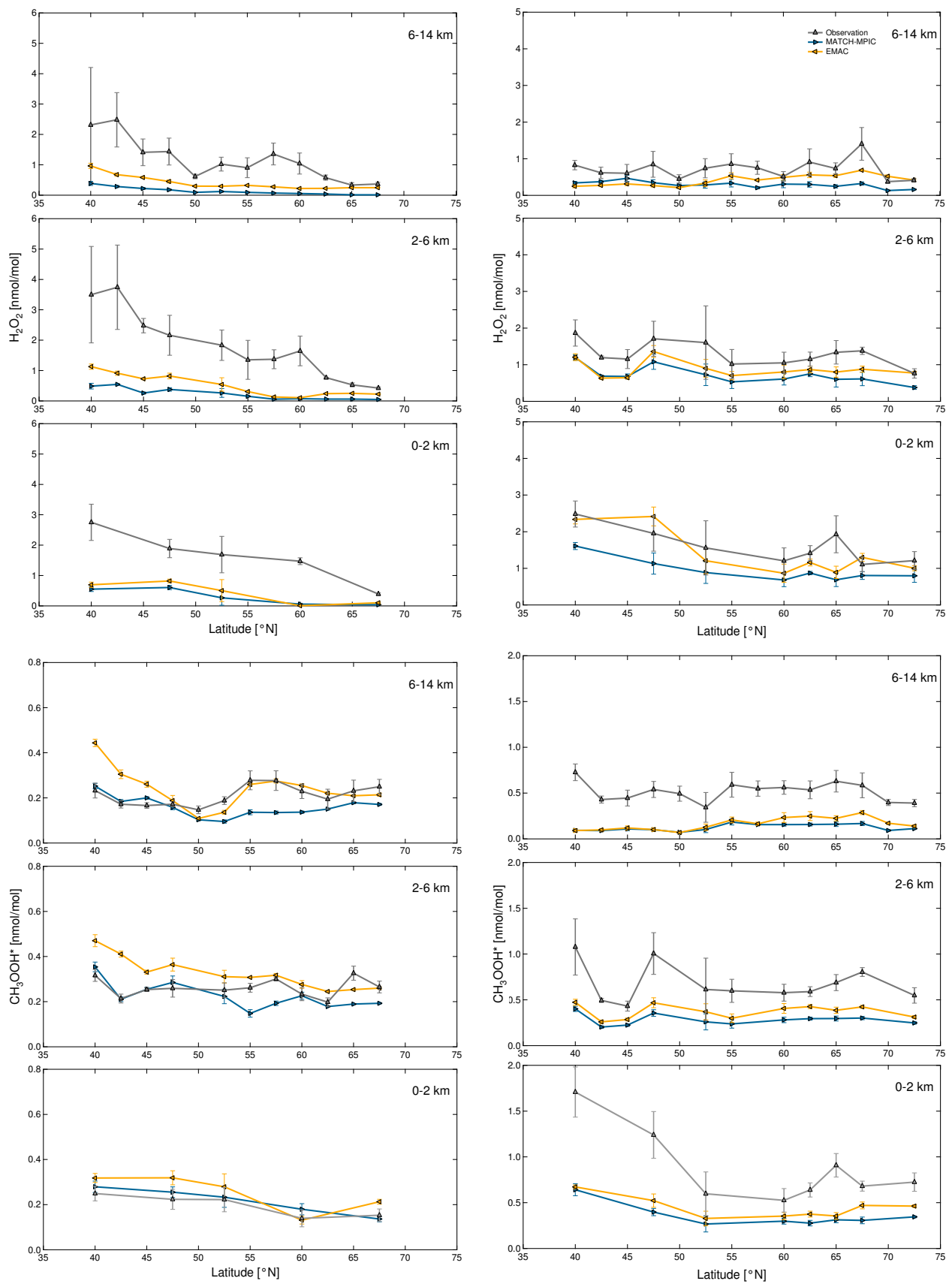

Fig. 7. Latitude gradients of $\mathrm{H}_{2} \mathrm{O}_{2}$ (upper panels) and $\mathrm{CH}_{3} \mathrm{OOH} *$ (lower panels) for HOOVER 1 in October 2006 (left panels) and HOOVER 2 in July 2007 (right panels). Data is subdivided into 3 altitude intervals representing the BL, the MT and the UT. The median values of in-situ measurements (grey), EMAC simulations (orange) and MATCH-MPIC simulations (blue) are shown together with 2 sigma as error bars.

clouds, including slow sedimentation of intermediate-sized frozen hydrometeors, can result in substantial variations in the vertical distribution of $\mathrm{H}_{2} \mathrm{O}_{2}$ in 3-D model simulations (Lawrence and Crutzen, 1998; Crutzen and Lawrence, 2000; Salzmann et al., 2007).

During the HOOVER mission, we were able to measure the inflow and outflow region of a large convective system over eastern Germany. The data, discussed in Bozem et al. (the influence of deep convection on formaldehyde and hydrogen peroxide in the upper troposphere over Europe, manuscript in preparation), shows that hydroperoxides and especially $\mathrm{H}_{2} \mathrm{O}_{2}$ can be quite effectively transported into the UT by convective updrafts within deep convective systems. The only other similar inflow and outflow measurements of 

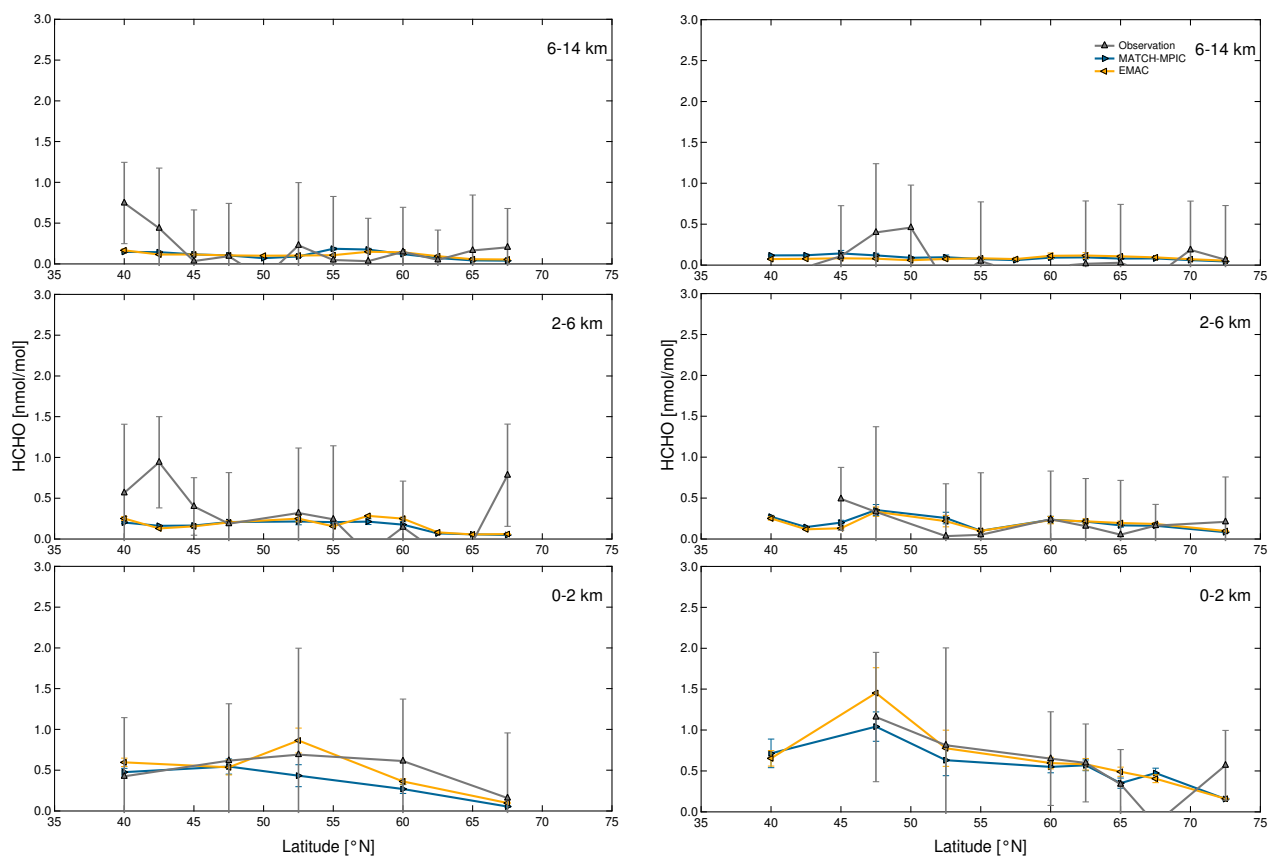

Fig. 8. Latitude gradients of HCHO for HOOVER 1 in October 2006 (left panels) and HOOVER 2 in July 2007 (right panels). Data is subdivided into 3 altitude intervals representing the BL, the MT and the UT. The median values of in-situ measurements (grey), EMAC simulations (orange) and MATCH-MPIC simulations (blue) are shown together with 2 sigma as error bars.
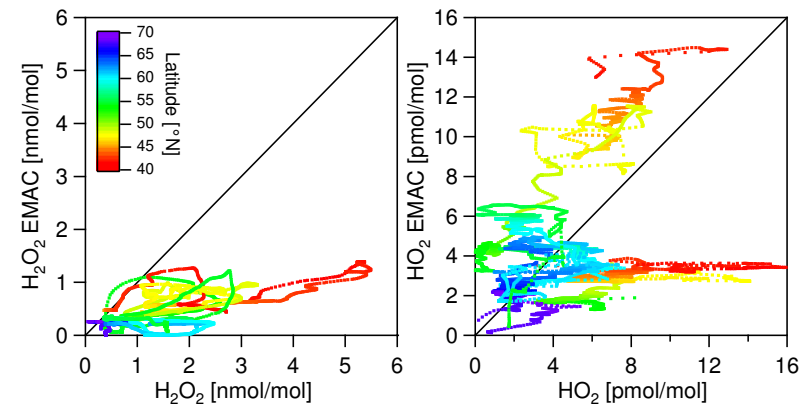

Fig. 9. Correlation of simulated $\mathrm{H}_{2} \mathrm{O}_{2}$ by EMAC with measured $\mathrm{H}_{2} \mathrm{O}_{2}$ and from simulated $\mathrm{HO}_{2}$ and measured $\mathrm{HO}_{2}$ during HOOVER 1 in October 2006. The data is colour coded by the latitude of sampling. Apart from the Mediterranean region (red and yellow), $\mathrm{HO}_{2}$ simulations reproduce the measured values reasonably well, whereas $\mathrm{H}_{2} \mathrm{O}_{2}$ is permanently underestimated by the model.

$\mathrm{H}_{2} \mathrm{O}_{2}$ which we are aware of are described by Mari et al. (2003), who explain their observations with an inefficent scavenging in glaciated clouds due to release of $\mathrm{H}_{2} \mathrm{O}_{2}$ into the UT during hydrometeor freezing, as mentioned above. Thus, it might be expected that the models will tend to overestimate $\mathrm{H}_{2} \mathrm{O}_{2}$ rainout. Therefore, a sensitivity study with the EMAC model was conducted to explore the role of cloud and rain scavenging on the budget of $\mathrm{H}_{2} \mathrm{O}_{2}$. A modified model setup for the autumn (H1) campaign was applied with deactivated gas-liquid transition of $\mathrm{H}_{2} \mathrm{O}_{2}$, so that loss reactions within cloud water and physical rain out processes were effectively switched off. A comparison of the in-situ data, the "standard" simulation and the simulation without $\mathrm{H}_{2} \mathrm{O}_{2}$ scavenging is shown in Fig. 10.

Neglecting rainout, the average simulated $\mathrm{H}_{2} \mathrm{O}_{2}$ mixing ratio more than doubles from $380 \mathrm{pmol} \mathrm{mol}^{-1}$ to $870 \mathrm{pmol} \mathrm{mol}^{-1}$ overall. The simulation of $\mathrm{H}_{2} \mathrm{O}_{2}$ improves drastically, especially at northern latitudes, where the modified simulation reproduces the in-situ data quite well, although it still underestimates the measured values in the southern parts of Europe and generally in the BL. This sensitivity study obviously represents extreme conditions that do not reflect the current understanding of $\mathrm{H}_{2} \mathrm{O}_{2}$ chemistry, especially considering the high solubility and depostion of $\mathrm{H}_{2} \mathrm{O}_{2}$. However, this example shows how sensitive the budget of $\mathrm{H}_{2} \mathrm{O}_{2}$ is to cloud scavenging and how the simulation improves without this sink. Up to now there is still a large uncertainty in the understanding of the critical criteria like retention factors and gas-liquid partitioning of the peroxides. We conclude that overestimation of cloud and rain scavenging of peroxides in models, and possibly also of other soluble species, is a potential source for the discrepancies between measurements and model simulations. 

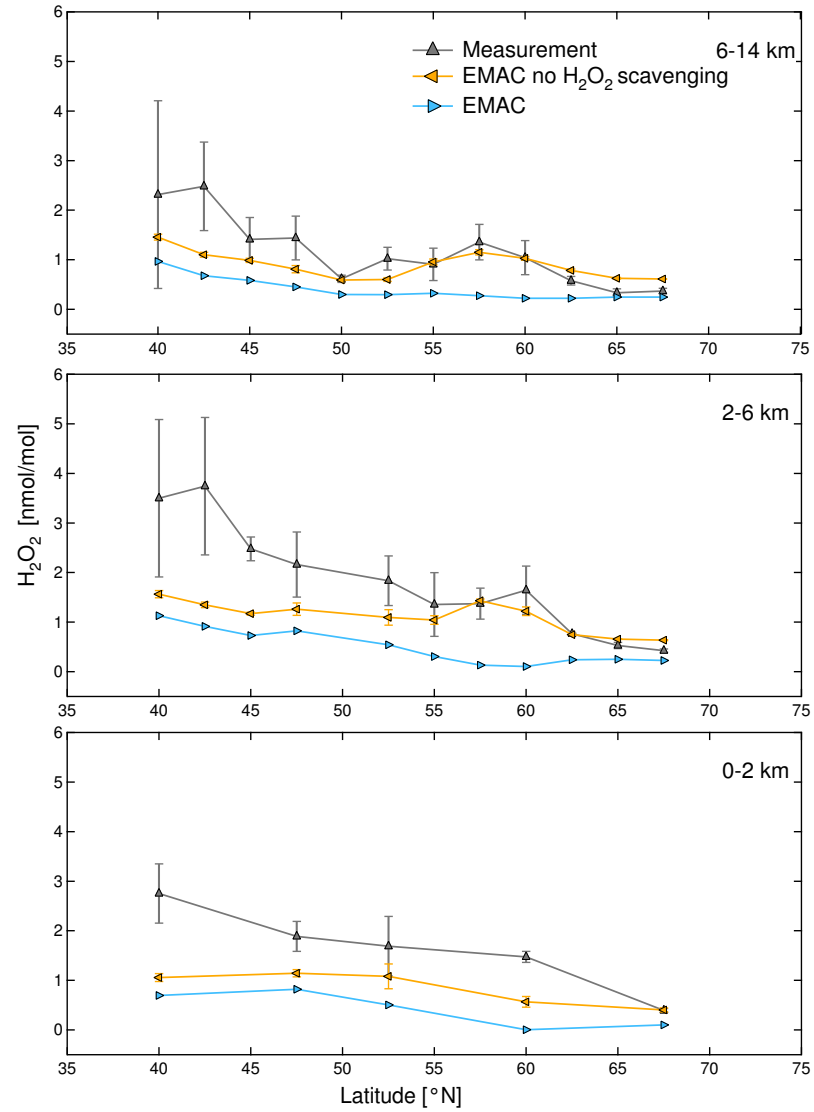

Fig. 10. Sensitivity study of $\mathrm{H} 1$ with the EMAC model. Latitude gradients of $\mathrm{H}_{2} \mathrm{O}_{2}$ for HOOVER 1 in October 2006: data is subdivided into 3 altitude intervals representing the BL, the MT and the UT. The median values of in-situ measurements (grey), standard EMAC simulations (blue) and EMAC simulations with deactivated cloud scavenging for $\mathrm{H}_{2} \mathrm{O}_{2}$ (orange) are plotted together with 2 sigma as error bars.

\subsection{The ratio of $\mathrm{H}_{2} \mathrm{O}_{2}$ to $\mathrm{CH}_{3} \mathrm{OOH} *$}

A systematic variation with altitude of the peroxide ratio is observed during both HOOVER campaigns as displayed in Fig. 11. The measured $\mathrm{H}_{2} \mathrm{O}_{2}$ to $\mathrm{CH}_{3} \mathrm{OOH} *$ ratio decreases with increasing altitude. In contrast, the simulated ratios show a C-shaped vertical profile with lowest values above the $\mathrm{BL}$ and increasing values in the UT. These shapes are strongly pronounced for the summer campaigns (HOOVER 2 and UTOPIHAN 2) and the winter/spring campaing (UTOPIHAN 3), whereas the autumn campaign (H1) shows a weaker increase of the peroxide ratio in the UT in the models. In order to understand whether these observation-model differences originate from photochemical calculations by the model and not from physical removal mechanisms or other parameterisations of the global models, calculations of the photochemical steady state concentrations were performed with the CAABA - box model, as constrained by the mea-
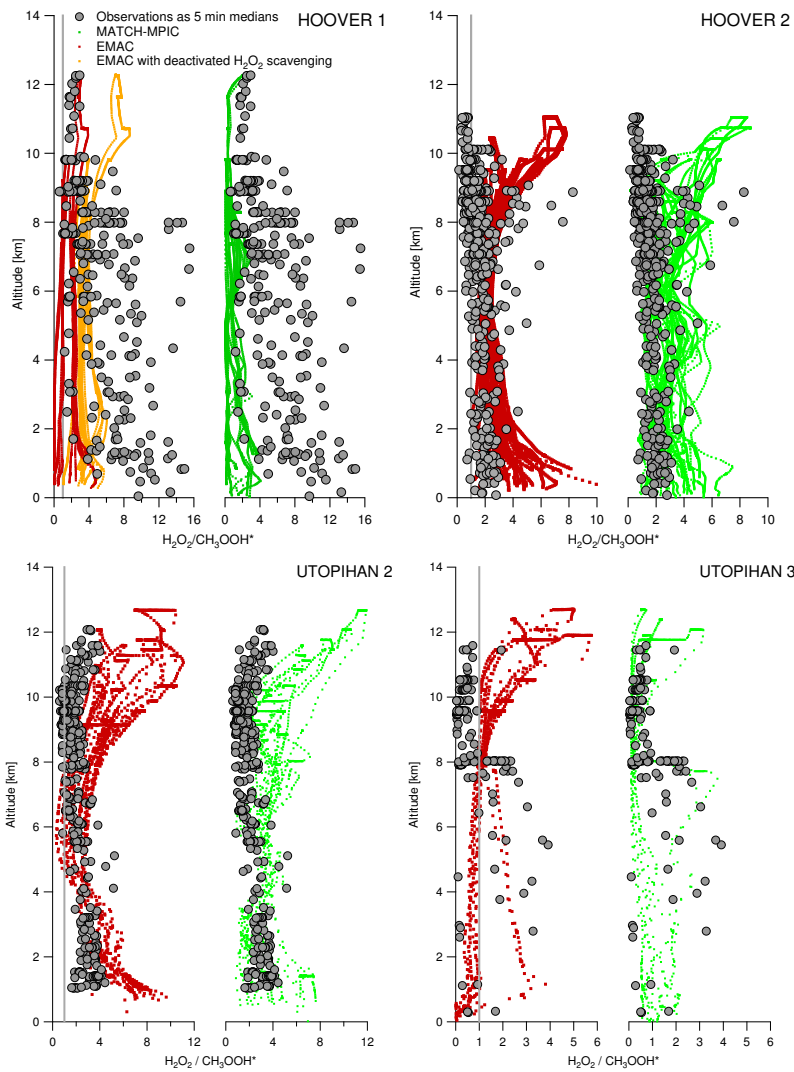

Fig. 11. The ratio $\mathrm{H}_{2} \mathrm{O}_{2} / \mathrm{CH}_{3} \mathrm{OOH} *$ as a function of altitude for UTOPIHAN 2, 3 and HOOVER 1, 2. Grey dots show observations averaged over $5 \mathrm{~min}$, red dots show data from the EMAC model, orange dots show EMAC data with deactivated cloud scavenging for $\mathrm{H}_{2} \mathrm{O}_{2}$ and green dots show MATCH-MPIC data.

surements. CAABA is based on the same atmospheric chemistry module MECCA that is used to calculate the chemistry within the EMAC model, and the tropospheric component of this was adopted and updated from the mechanism used in MATCH-MPIC, so that all three models include very similar tropospheric chemical reactions. The results of the box model calculations for the HOOVER 2 campaign are displayed as timeseries in Fig. 12. These box model simulations give $\mathrm{H}_{2} \mathrm{O}_{2}$ to $\mathrm{CH}_{3} \mathrm{OOH} *$ ratios of about 1.7 for the $\mathrm{BL}, 1.5$ for the MT and 1.8 for the UT after a simulated period of 8 days. These ratios are smaller compared to the ones calculated from the the EMAC model (shown in Fig. 11). However, the box model calculations were initiated with median values of the altitude dependent measured species. Therefore the calculations represent a "median" model calculation as well. However, there is the same tendency seen in the box model calculations with a higher ratio in the $\mathrm{BL}$, a reduced ratio in the MT and an increasing ratio in the UT, in contradiction to the observed decrease with height during the HOOVER campaign. 

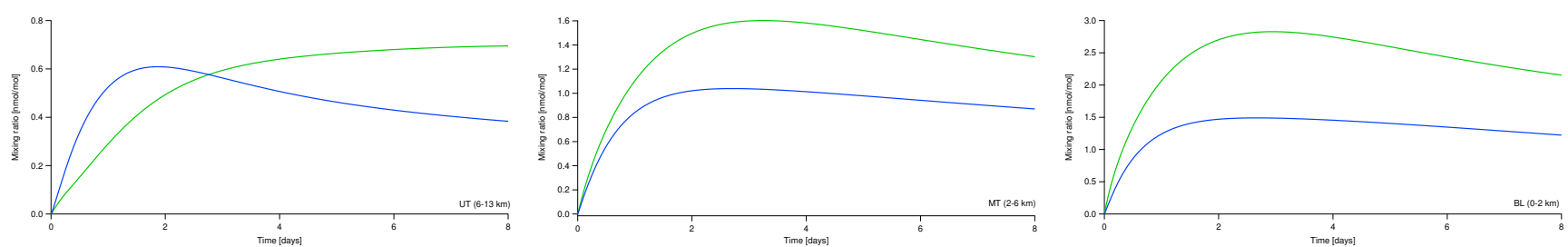

Fig. 12. Mixing ratios for $\mathrm{H}_{2} \mathrm{O}_{2}$ (blue line) and $\mathrm{CH}_{3} \mathrm{OOH} *$ (green line) from CAABA for the upper troposphere. Production is initialised from zero and shown for three different height intervals.

In previous studies, the ratio of $\mathrm{H}_{2} \mathrm{O}_{2}$ to $\mathrm{CH}_{3} \mathrm{OOH}$ has been used as an indicator for recent processing of an air parcel by convection (Heikes et al., 1996b; O'Sullivann et al., 1999; Snow et al., 2003, 2007). Airmasses with a ratio of $\geq 3$ were thought to be associated with free tropospheric conditions, while ratios of $\leq 1$ were thought to be associated with airmasses recently processed by convection. It is well known that convective systems can transport insoluble pollutants effectively from boundary layer regions to the middle and upper troposphere (e.g. Isaac and Joe, 1983; Chatfield and Crutzen, 1984; Dickerson et al., 1987). The method identifying cloud processing via the peroxide ratio relies on the assumption that soluble species are effectively scavenged during cloud processing (e.g. Hales and Dana, 1979; Wang and Crutzen, 1995; Crutzen and Lawrence, 2000). They dissolve into the cloud droplets followed by subsequent aqueous phase reactions and physical removal through precipitation. Here $\mathrm{H}_{2} \mathrm{O}_{2}$ is removed more efficiently than $\mathrm{CH}_{3} \mathrm{OOH}$ due to its higher solubility (Henry's law constant of $7.73 \times 10^{4} \mathrm{M} \mathrm{atm}^{-1}$ at $298 \mathrm{~K}$ for $\mathrm{H}_{2} \mathrm{O}_{2}$ compared to $300 \mathrm{M} \mathrm{atm}^{-1}$ at $298 \mathrm{~K}$ for $\mathrm{CH}_{3} \mathrm{OOH}$, Sander et al., 2003). Thus, air in the outflow region of a convective system is expected to contain enhanced levels of $\mathrm{CH}_{3} \mathrm{OOH}$ relative to $\mathrm{H}_{2} \mathrm{O}_{2}$. However, as we will show based on our observations, the process might be more complex.

For the UTOPIHAN-ACT 2 campaign Stickler et al. (2006) discussed and compared a "background case" during flight UT07 and a "convective case" during flight UT04. Time series of these two flights are shown in Fig. 13. The background case of UT07 is characterised by low CO and $\mathrm{O}_{3}$ values, low water vapour and low values for both peroxides in the range of $200-600 \mathrm{pmol} \mathrm{mol}^{-1}$. The peroxide ratio is generally around $2-3$ throughout the entire flight. During the convective case (UT 04:00) measured in the outflow remnants of a thunderstorm during the preceeding day, higher $\mathrm{CO}$ values and increased water vapour content were measured. Both peroxides show significantly elevated levels, up to more than $1 \mathrm{nmol} \mathrm{mol}^{-1}$ in the UT for $\mathrm{H}_{2} \mathrm{O}_{2}$. However, the peroxide ratio stays well above unity and is comparable to the background case, which would lead by itself to a misinterpretation of this data according to the peroxide ratio filtering. In HOOVER flight H08 (summer), we were also able to
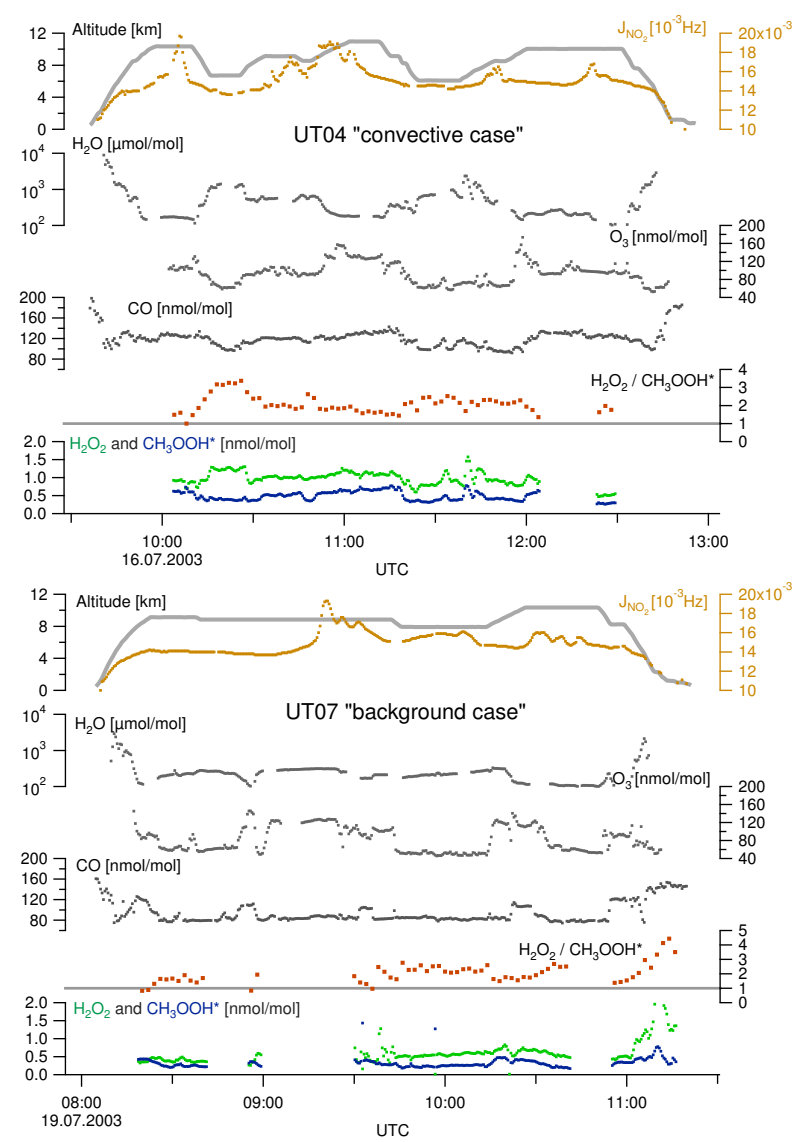

Fig. 13. The usage of the $\mathrm{H}_{2} \mathrm{O}_{2} / \mathrm{CH}_{3} \mathrm{OOH} *$ ratio as indicator for recent convective influence on an airmass. Time series of UTOPIHAN flights 04 and 07 representing the "convective" (UT 04:00) and "background" (UT 07:00) case. The peroxide ratio is in the range of 2-4 overall for both flights although the effect of preceeding convective injection during the previous day can be clearly seen during UT 04:00 in CO, water vapour and enhanced peroxide levels in the upper troposphere.

sample an outflow region of a convective system over southern Germany. The flight is shown in Fig. 14. Elevated levels of $\mathrm{CO}$ and water vapour indicate convective outflow being measured in the grey shaded boxes. Significantly elevated 

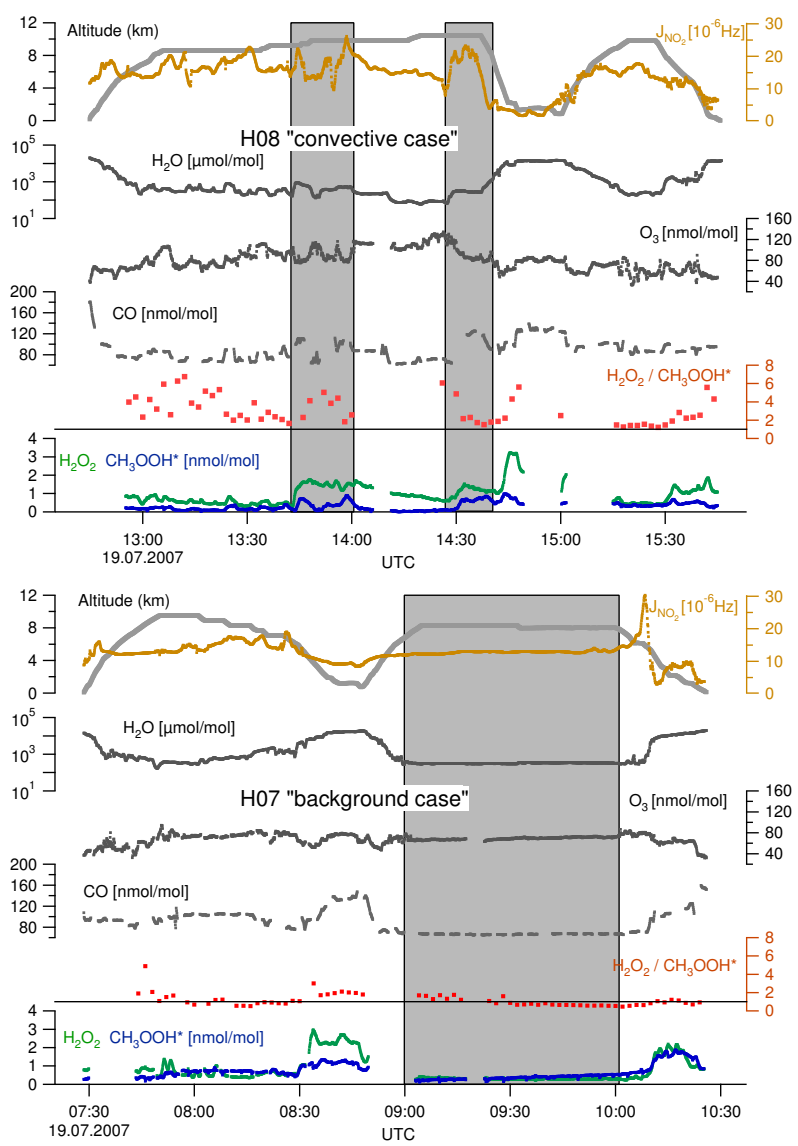

Fig. 14. The usage of the $\mathrm{H}_{2} \mathrm{O}_{2} / \mathrm{CH}_{3} \mathrm{OOH} *$ ratio as indicator for recent convective influence on an airmass. Time series of HOOVER flights 07 and 08 representing the "convective" (H 08) and "background" ( $\mathrm{H} 07)$ case. The peroxide ratio is in the range of $2-4$ overall for flight $\mathrm{H} 08$, and the effect of convective injection can be seen in the grey shaded boxes in $\mathrm{CO}$, water vapour and enhanced peroxide levels in the upper troposphere. In contrast, the grey shaded box during flight 07 shows a chemically aged airmass with low and flat time series for $\mathrm{CO}, \mathrm{O}_{3}$, water vapour and peroxide but nevertheless shows peroxide ratios around and even below unity.

levels of peroxides were also measured, in agreement with the UT04 flight, indicating effective transport of both peroxides, resulting in an overall peroxide ratio of $2-3$. In contrast to these findings, the lower panel of Fig. 14 shows flight H07 (summer), which has been characterised as a photochemical "background" flight. $\mathrm{CO}, \mathrm{O}_{3}$ and peroxides show low, almost constant mixing ratios indicating chemically aged and unperturbed airmasses. However, although recent convective influence can be ruled out, the peroxide ratio drops below unity, which would indicate "recently convectively influenced" airmasses according to the data filtering method described above.

The measurements discussed above from the UTOPIHAN and HOOVER campaigns provide strong evidence that deep convective systems at the midlatitudes can transport both, highly soluble $\mathrm{H}_{2} \mathrm{O}_{2}$ and less soluble $\mathrm{CH}_{3} \mathrm{OOH}$ effectively to the upper troposphere, in agreement with some publications (Snider et al., 1992; Barth et al., 2001b, 2003; Salzmann et al., 2007). In a study by Kim et al. (2002), as pointed out earlier, it is shown that cloud processing of airmasses may have different effects on the mixing ratios of $\mathrm{H}_{2} \mathrm{O}_{2}$ depending on the general chemical conditions, including $\mathrm{NO}_{\mathrm{x}}$ concentrations and the time of day. The scavenging efficiency is also strongly dependent on the temperature of the cloud, the state of the hydrometeors and on the $\mathrm{SO}_{2}$ concentration within the aqueous phase, which reacts with $\mathrm{H}_{2} \mathrm{O}_{2}$ molecules (Penkett et al., 1979; Heikes et al., 1987; Mohnen and Kadlecek, 1989; Penkett et al., 1989; Clegg and Abbatt, 2001).

\section{Conclusions}

The HOOVER measurements reveal gradients in latitude, altitude and across the season in the mixing ratios of hydroperoxides and $\mathrm{HCHO}$. Latitudinal gradients are less pronounced in autumn than during summer. We find decreasing values for all species with increasing latitude. $\mathrm{H}_{2} \mathrm{O}_{2}$ shows the strongest variations followed by $\mathrm{CH}_{3} \mathrm{OOH} *$. The latitudinal gradients are less pronounced with height and vanish towards the tropopause region. Formaldehyde is rather homogeneously distributed compared to the peroxides except for elevated concentrations over the Mediterranean, which is characterised by the highest mixing ratios for the species discussed. All species have declining mixing ratios with height due to decreasing radical precursors. The peroxides show distinct vertical maxima in the free troposphere at 2 $5 \mathrm{~km}$ which are more pronounced in the south and almost vanish at northern latitudes. Lower concentrations typical for the lower $2 \mathrm{~km}$ are associated with enhanced sink processes, i.e. dry and wet deposition. HCHO shows declining mixing ratios with height, but is sometimes elevated in the UT, which can be attributed to increasing $\mathrm{NO}_{\mathrm{x}}$ levels that play a crucial role in $\mathrm{HCHO}$ formation. There is a relatively small difference in absolute mixing ratios between autumn and summer for $\mathrm{H}_{2} \mathrm{O}_{2}$, while $\mathrm{CH}_{3} \mathrm{OOH} *$ mixing ratios vary by more than a factor of 2 from summer to autumn. $\mathrm{HCHO}$ remains almost constant with latitude, with the exception of the Mediterranean, where strong enhancements occur. Overall, the HOOVER 2 summer measurements compare well to the INTEX-NA campaign over North America in terms of absolute values, vertical trends and geographical gradients for the peroxides. Formaldehyde mixing ratios are almost half compared to the INTEX-NA observations but show similar altitude profiles. Overall we find less seasonal variation over Europe than over North America, although this needs to be verified by additional measurements.

The 3-D model simulations of $\mathrm{H}_{2} \mathrm{O}_{2}, \mathrm{CH}_{3} \mathrm{OOH}$ and HCHO show similar distributions compared to the observations with respect to altitude and latitude patterns. However, the models have problems to reproduce the absolute values, 
especially for $\mathrm{H}_{2} \mathrm{O}_{2}$. Uncertainties reported from the literature concerning the quantitative impact of cloud and rain scavenging on the budget of $\mathrm{H}_{2} \mathrm{O}_{2}$ and measurement evidence have inspired a model sensitivity study with deactivated scavenging of $\mathrm{H}_{2} \mathrm{O}_{2}$ in EMAC. This shows that the parameterisation of cloud scavenging could be a potentially important source of error within the model. The improvement of $\mathrm{H}_{2} \mathrm{O}_{2}$ simulations with deactivated scavenging points to too efficient scavenging in the model. The HOOVER observations described here show that the soluble species $\mathrm{H}_{2} \mathrm{O}_{2}$ can be effectively transported to the UT by deep convection, which is unexpected considering its high solubility.

Acknowledgements. The authors are very greatful to the HOOVER team, Enviscope $\mathrm{GmbH}$ and the Gesellschaft für Flugzieldarstellung (GFD) for their great support. Their work was instrumental for the HOOVER project.

The service charges for this open access publication have been covered by the Max Planck Society.

Edited by: T. Bertram

\section{References}

Arlander, D. W., Brüning, D., Schmidt, U., and Ehhalt, D. H.: The tropospheric distribution of formaldehyde during TROPOZ II, J. Atmos. Chem., 2, 251-268, 1995.

Atkinson, R.: Gas-phase tropospheric chemistry of organic compounds., Journal of Physical and Chemical Reference Data, Monograph 2, 1-216, 1994.

Balasubramanian, R. and Husain, L.: Observations of gas-phase hydrogen peroxide at an elevated rural site in New York, J. Geophys. Res., 102, 21209-21220, 1997.

Barth, M. C., Skamarock, W., and Stuart, A.: Numerical simulations of the July 10, 1996, Stratospheric-Tropospheric Experiment: Radiation, Aerosols, and Ozone(STERAO)-Deep Convection experiment storm- Redistribution of soluble tracers, J. Geophys. Res., 106, 12381-12400, 2001a.

Barth, M. C., Stuart, A. L., and Skamarock, W. C.: Numerical simulations of the July 10, 1996, Stratospheric-Tropospheric Experiment: Radiation, Aerosols, and Ozone (STERAO) - Deep Convection experiment storm: Redistribution of soluble tracers, J. Geophys. Res., 106, 12381-12400, 2001b.

Barth, M. C., Sillman, S., Hudman, R., Jacobson, M. Z., Kim, C.H., Monod, A., and Liang, J.: Summary of the cloud chemistry modeling intercomparison: Photochemical box model simulation, J. Geophys. Res., 108, 4214, doi:10.1029/2002JD002673, 2003.

Barth, M. C., Kim, S., Skamarock, W., Stuart, A., Pickering, K., and Ott, L.: Simulations of the redistribution of formaldehyde, formic acid, and peroxides in the 10 July 1996 StratosphericTropospheric Experiment: Radiation, Aerosols, and Ozone deep convection storm, J. Geophys. Res.-Atmos., 112, D13310, doi:10.1029/2006JD008046, 2007.

Calvert, J., Lazrus, A., Kok, G., Heikes, B. G., Walega, J., Lind, J., and Cantrell, C.: Chemical mechanisms of acid generation in the troposphere, Nature, 317, 27-35, 1985.
Cantrell, C. A., Mauldin, L., Zondlo, M., Eisele, F., Kosciuch, E., Shetter, R., Lefer, B., Hall, S., Campos, T., Ridley, B., Walega, J., Fried, A., Wert, B., Flocke, F., Weinheimer, A., Hannigan, J., Coffey, M., Atlas, E., Stephens, S., Heikes, B. G., Snow, J., Blake, D., Blake, N., Katzenstein, A., Lopez, J., Browell, E. V., Dibb, J., Scheuer, E., Seid, G., and Talbot, R.: Steady state free radical budgets and ozone photochemistry during TOPSE, J. Geophys. Res., 108, 8361, doi:10.1029/2002JD002198, 2003.

Chatfield, R. B. and Crutzen, P. J.: Sulfur dioxide in remote oceanic air: cloud transport of reactive precursors, J. Geophys. Res., 89, 7111-7132, 1984.

Clegg, S. and Abbatt, J.: Uptake of gas-phase SO 2 and $\mathrm{H} 2 \mathrm{O} 2$ by ice surfaces: dependence on partial pressure, temperature, and surface acidity, J. Phys. Chem. A, 105, 6630-6636, 2001.

Colomb, A., Williams, J., Crowley, J., Gros, V., Hofmann, R., Salisbury, G., Klupfel, T., Kormann, R., Stickler, A., Forster, C., and Lelieveld, J.: Airborne measurements of trace organic species in the upper troposphere over Europe: the impact of deep convection, Environ. Chem., 3, 244-259, 2006.

Conklin, M. H., Sigg, A., Neftel, A., and Bales, R. C.: Atmospheresnow transfer function for $\mathrm{H}_{2} \mathrm{O}_{2}$ : Microphysical considerations, J. Geophys. Res., 98, 18367-18376, 1993.

Crutzen, P. J. and Lawrence, M. G.: The impact of precipitation scavenging on the transport of trace gases: a 3-dimensional model sensitivity study, J. Atmos. Chem., 37, 81-112, 2000.

Crutzen, P. J., Lawrence, M., and Pöschl, U.: On the background photochemistry of tropospheric ozone, Tellus A, 51, 123-146, 1999.

Daum, P. H., Kleinman, L. I., Hills, A. J., Lazrus, A. L., Leslie, A. C. D., Busness, K., and Boatman, J.: Measurement and interpretation of concentrations of $\mathrm{H}_{2} \mathrm{O}_{2}$ and related species in the upper midwest during summer, J. Geophys. Res., 95, 9857-9871, 1990.

Dickerson, R. R., Huffman, G. J., Luke, W. T., Nunnermacker, L. J., Pickering, K. E., Leslie, A. C. D., Lindsey, C. G., Slinn, W. G. N., Kelly, T. J., Daum, P. H., Delany, A. C., Greenberg, J. P., Zimmerman, P. R., Boatman, J. F., Ray, J. D., and Stedman, D. H.: Thunderstorms: An important mechanism in the transport of air pollutants, Science, 235, 460-465, 1987.

Dufour, G., Szopa, S., Barkley, M. P., Boone, C. D., Perrin, A., Palmer, P. I., and Bernath, P. F.: Global uppertropospheric formaldehyde: seasonal cycles observed by the ACE-FTS satellite instrument, Atmos. Chem. Phys., 9, 38933910, doi:10.5194/acp-9-3893-2009, 2009.

Faloona, I., Tan, D., Brune, W., Jaeglé, L., Jacob, D., Kondo, Y., Koike, M., Chatfield, R., Pueschel, R., Ferry, G., Sachse, G., Vay, S., Anderson, B., Hannon, J., and Fuelberg, H.: Observations of $\mathrm{HO}_{\mathrm{x}}$ and its relationship with $\mathrm{NO}_{\mathrm{x}}$ in the upper troposphere during SONEX, J. Geophys. Res., 105, 3771-3783, 2000.

Fried, A., Lee, Y., Frost, G., Wert, B., Henry, B., Drummond, J., Hubler, G., and Jobson,T.: Airborne $\mathrm{CH}_{2} \mathrm{O}$ measurements over the North Atlantic during the 1997 NARE campaign: instrument comparisons and distributions, J. Geophys. Res.-Atmos., 107(D4), 4039, doi:10.1029/2000JD000260, 2002.

Fried, A., Crawford, J., Olson, J., Walega, J., Potter, W., Wert, B., Jordan, C., Anderson, B., Shetter, R., Lefer, B., Blake, D., Blake, N., Meinardi, S., Heikes, B. G., OSullivan, D., Snow, J., Fuelberg, H., Kiley, C. M., Sandholm, S., Tan, D., Sachse, G., Singh, H., Faloona, I., Harward, C. N., and Carmichael, G. R.: Airborne tunable diode laser measurements of formaldehyde during 
TRACE-P: Distributions and box model comparisons, J. Geophys. Res., 108, 8798, doi:10.1029/2003JD003451, 2003a.

Fried, A., Wang, Y., Cantrell, C., Wert, B., Walega, J., Ridley, B., Atlas, E., Shetter, R., Lefer, B., Coffey, M. T., Hannigan, J., Blake, B., Blake, N., Meinardi, S., Talbot, B., Dibb, J., Scheuer, E., Wingenter, O., Snow, J., Heikes, B. G., and Ehhalt, D.: Tunable diode laser measurements of formaldehyde during the TOPSE 2000 study: Distributions, trends, and model comparisons, J. Geophys. Res., 108, 8365, doi:10.1029/2002JD002208, 2003 b.

Hales, J. and Dana, M.: Precipitation scavenging of urban pollutants by convective storm systems, J. Appl. Meteorol., 18, 294-316, 1979.

Hall, B. and Claiborn, C.: Measurements of the dry deposition of peroxides to a Canadian boreal forest, J. Geophys. Res, 102, 29343-29353, 1997.

Hall, B., Claiborn, C., and Baldocchi, D.: Measurement and modeling of the dry deposition of peroxides, Atmos. Environ., 33, 577-589, 1999.

Heikes, B. G.: Formaldehyde and hydroperoxides at Mauna Loa Observatory, J. Geophys. Res., 97, 18001-18013, 1992.

Heikes, B. G., Kok, G. L., Walega, J. G., and Lazrus, A. L.: $\mathrm{H}_{2} \mathrm{O}_{2}$, $\mathrm{O}_{3}$ and $\mathrm{SO}_{2}$ measurements in the lower troposphere over the eastern United States during fall, J. Geophys. Res., 92, 915-931, 1987.

Heikes, B. G., Lee, M., Jacob, D., Talbot, R., Bradshaw, J., Singh, H., Blake, D., Anderson, B., Fuelberg, H., and Thompson, A. M.: Ozone, hydroperoxides, oxides of nitrogen, and hydrocarbon budgets in the marine boundary layer over the South Atlantic, J. Geophys. Res., 101, 24221-24234, 1996a.

Heikes, B. G., Lee, M., Bradshaw, J., Sandholm, S., Davis, D. D., Crawford, J., Rodriguez, J., Liu, S., McKeen, S., Thornton, D., Bandy, A., Gregory, G., Talbot, R., and Blake, D.: Hydrogen peroxide and methylhydroperoxide distributions related to ozone and odd hydrogen over the North Pacific in the fall of 1991, J. Geophys. Res., 101, 1891-1905, 1996 b.

Heikes, B. G., Snow, J., Egli, P., OSullivan, D., Crawford, J., Olson, J., Chen, G., Davis, D., Blake, N., and Blake, D.: Formaldehyde over the central Pacific during PEM-Tropics B, J. Geophys. Res., 101, 14741-14755, 2001.

Hua, W., Chen, Z. M., Jie, C. Y., Kondo, Y., Hofzumahaus, A., Takegawa, N., Chang, C. C., Lu, K. D., Miyazaki, Y., Kita, K., Wang, H. L., Zhang, Y. H., and Hu, M.: Atmospheric hydrogen peroxide and organic hydroperoxides during PRIDE-PRD'06, China: their concentration, formation mechanism and contribution to secondary aerosols, Atmos. Chem. Phys., 8, 6755-6773, doi:10.5194/acp-8-6755-2008, 2008.

Iribarne, J. V. and Pyshnov, T.: The effect of freezing on the composition of cloud droplets - I. Retention of $\mathrm{HCl}, \mathrm{HNO}_{3}, \mathrm{NH}_{3}$, and $\mathrm{H}_{2} \mathrm{O}_{2}$, Atmos. Environ., 24A, 383-387, 1990.

Isaac, G. and Joe, P.: The vertical transport and redistribution of pollutants by clouds, The Meteoroloy of Acid Deposition, Air Pollution Control Association, Pittsburgh, PA, USA, 496-512, 1983.

Jackson, A. V. and Hewitt, C. N.: Hydrogen peroxide and organic hydroperoxide concentrations in a Eucalyptus forest in central Portugal, Atmos. Environ., 30, 819-830, 1996.

Jacob, P. and Klockow, D.: Hydrogen peroxide measurements in the marine atmosphere, J. Atmos. Chem., 15, 353-360, 1992.
Jaeglé, L., Jacob, D. J., Wennberg, P. O., Spivakovsky, C. M., Hanisco, T. F., Lanzendorf, E. J., Hintsa, E. J., Fahey, D. W., Keim, E. R., Proffitt, M. H., Atlas, E. L., Flocke, F., Schauffler, S., McElroy, C. T., Midwinter, C., Pfister, L., and Wilson, J. C.: Observed $\mathrm{OH}$ and $\mathrm{HO}_{2}$ in the upper troposphere suggest a major source from convective injection of peroxides, Geophys. Res. Let., 24, 3181-3184, 1997.

Jaeglé, L., Jacob, D. J., Brune, W. H., Faloona, I., Tan, D., Heikes, B. G., Kondo, Y., Sachse, G. W., Anderson, B., Gregory, G. L., Singh, H. B., Pueschel, R., Ferry, G., Blake, D. R., and Shetter, R. E.: Photochemistry of $\mathrm{HO}_{x}$ in the upper troposphere at northern midlatitudes, J. Geophys. Res., 105, 3877-3892, 2000.

Jöckel, P., Sander, R., Kerkweg, A., Tost, H., and Lelieveld, J.: Technical Note: The Modular Earth Submodel System (MESSy) - a new approach towards Earth System Modeling, Atmos. Chem. Phys., 5, 433-444, doi:10.5194/acp-5-433-2005, 2005.

Jöckel, P., Tost, H., Pozzer, A., Brühl, C., Buchholz, J., Ganzeveld, L., Hoor, P., Kerkweg, A., Lawrence, M. G., Sander, R., Steil, B., Stiller, G., Tanarhte, M., Taraborrelli, D., van Aardenne, J., and Lelieveld, J.: The atmospheric chemistry general circulation model ECHAM5/MESSy 1: consistent simulation of ozone from the surface to the mesosphere, Atmos. Chem. Phys., 6, 50675104, doi:10.5194/acp-6-5067-2006, 2006.

Jöckel, P., Kerkweg, A., Pozzer, A., Sander, R., Tost, H., Riede, H., Baumgaertner, A., Gromov, S., and Kern, B.: Development cycle 2 of the Modular Earth Submodel System (MESSy2), Geosci. Model Dev., 3, 717-752, doi:10.5194/gmd-3-717-2010, 2010.

Kerkweg, A., Buchholz, J., Ganzeveld, L., Pozzer, A., Tost, H., and Jöckel, P.: Technical Note: An implementation of the dry removal processes DRY DEPosition and SEDImentation in the Modular Earth Submodel System (MESSy), Atmos. Chem. Phys., 6, 4617-4632, doi:10.5194/acp-6-4617-2006, 2006 a.

Kerkweg, A., Sander, R., Tost, H., and Jöckel, P.: Technical note: Implementation of prescribed (OFFLEM), calculated (ONLEM), and pseudo-emissions (TNUDGE) of chemical species in the Modular Earth Submodel System (MESSy), Atmos. Chem. Phys., 6, 3603-3609, doi:10.5194/acp-6-3603-2006, 2006 b.

Kim, C.-H., Kreidenweis, S. M., Feingold, G., Frost, G. J., and Trainer, M. K.: Modeling cloud effects on hydrogen peroxide and methylhydroperoxide in the marine atmosphere, J. Geophys. Res., 107, 4018, doi:10.1029/2000JD000285, 2002.

Kleinman, L. I.: Photochemical formation of peroxides in the boundary layer, J. Geophys. Res., 91, 10889-10904, 1986.

Kormann, R., Fischer, H., de Reus, M., Lawrence, M., Brühl, Ch., von Kuhlmann, R., Holzinger, R., Williams, J., Lelieveld, J., Warneke, C., de Gouw, J., Heland, J., Ziereis, H., and Schlager, H.: Formaldehyde over the eastern Mediterranean during MINOS: Comparison of airborne in-situ measurements with 3D-model results, Atmos. Chem. Phys., 3, 851-861, doi:10.5194/acp-3-851-2003, 2003.

Kunen, S., Lazrus, A., Kok, G., and Heikes, B. G.: Aqueous oxidation of SO2 by hydrogen peroxide, J. Geophys. Res., 88, 36713674, 1983.

Lawrence, M. G. and Crutzen, P.: The impact of cloud particle gravitational settling on soluble trace gas distributions, Tellus B, 50, 263-289, 1998.

Lawrence, M. G., Rasch, P. J., von Kuhlmann, R., Williams, J., Fischer, H., de Reus, M., Lelieveld, J., Crutzen, P. J., Schultz, M., Stier, P., Huntrieser, H., Heland, J., Stohl, A., Forster, C., Elbern, 
H., Jakobs, H., and Dickerson, R. R.: Global chemical weather forecasts for field campaign planning: predictions and observations of large-scale features during MINOS, CONTRACE, and INDOEX, Atmos. Chem. Phys., 3, 267-289, doi:10.5194/acp-3267-2003, 2003.

Lazrus, A. L., Kok, G. L., Gitlin, S. N., and Lind, J. A.: Automated fluorometric method for hydrogen peroxide in atmospheric precipitation, Anal. Chem., 57, 917-922, 1985.

Lazrus, A. L., Kok, G. L., Lind, J. A., Gitlin, S. N., Heikes, B. G., and Shetter, R. E.: Automated fluorometric method for hydrogen peroxide in air, Anal. Chem., 58, 594-597, 1986.

Lee, M., Heikes, B. G., Jacob, D. J., Sachse, G., and Anderson, B.: Hydrogen peroxide, organic hydroperoxide, and formaldehyde as primary pollutants from biomass burning, J. Geophys. Res., 102, 1301-1309, 1997.

Lee, M. H., Heikes, B. G., and O'Sullivan, D. W.: Hydrogen peroxide and organic hydroperoxide in the troposphere: A review, Atmos. Environ., 34, 3475-3494, 2000.

Lelieveld, J. and Crutzen, P. J.: Influence of cloud photochemical processes on tropospheric ozone, Nature, 343, 227-233, 1990.

Lelieveld, J., Berresheim, H., Borrmann, S., Crutzen, P., Dentener, F., Fischer, H., Feichter, J., Flatau, P., Heland, J., Holzinger, R., et al.: Global air pollution crossroads over the Mediterranean, Science, 298, 794-799, 2002.

Lightfoot, P., Cox, R., Crowley, J., Destriau, M., Hayman, G., Jenkin, M., Moortgat, G., and Zabel, F.: Organic peroxy radicals: kinetics, spectroscopy and tropospheric chemistry, Atmos. Environ. Part A, 26, 1805-1961, 1992.

Logan, J. A., Prather, M. J., Wofsy, S. C., and McElroy, M. B.: Tropospheric chemistry: A global perspective, J. Geophys. Res., 86, 7210-7254, 1981.

Mari, C., Saüt, C., Jacob, D. J., Staudt, A., Avery, M. A., Brune, W. H., Faloona, I., Heikes, B. G., Sachse, G. W., Sandholm, S. T., Singh, H. B., and Tan, D.: On the relative role of convection, chemistry, and transport over the South Pacific Convergence Zone during PEM-Tropics B: A case study, J. Geophys. Res., 108, 8232, doi:10.1029/2001JD001466, 2003.

Martinez, M., Harder, H., Kubistin, D., Rudolf, M., Bozem, H., Eerdekens, G., Fischer, H., Klüpfel, T., Gurk, C., Königstedt, R., Parchatka, U., Schiller, C. L., Stickler, A., Williams, J., and Lelieveld, J.: Hydroxyl radicals in the tropical troposphere over the Suriname rainforest: airborne measurements, Atmos. Chem. Phys., 10, 3759-3773, doi:10.5194/acp-10-3759-2010, 2010.

Mohnen, V. A. and Kadlecek, J. A.: Cloud chemistry research at Whiteface Mountain, Tellus, 41B, 79-91, 1989.

Nunnermacker, L. J., Weinstein-Lloyd, J. B., Hillery, B., Giebel, B., Kleinman, L. I., Springston, S. R., Daum, P. H., Gaffney, J., Marley, N., and Huey, G.: Aircraft and ground-based measurements of hydroperoxides during the 2006 MILAGRO field campaign, Atmos. Chem. Phys., 8, 7619-7636, doi:10.5194/acp8-7619-2008, 2008.

O'Sullivan, D. W., Heikes, B. G., Lee, M., Chang, W., Gregory, G. L., Blake, D. R., and Sachse, G. W.: Distributions of hydrogen peroxide and methylhydroperoxide over the Pacific and South Atlantic Oceans, J. Geophys. Res., 104, 5635-5646, 1999.

O’Sullivan, D. W., Heikes, B. G., Snow, J., Burrow, P., Avery, M., Blake, D. R., Sachse, G. W., D. C. Thornton, R. W. T., and Bandy, A. R.: Long-term and seasonal variations in the levels of hydrogen peroxide, methylhydroperoxide, and selected com- pounds over the Pacific Ocean, J. Geophys. Res., 109, D15S13, doi:10.1029/2003JD003689, 2004.

Palenik, B., Zafiriou, O. C., and Morel, F. M. M.: Hydrogen peroxide production by a marine phytoplankter, Limnol. Oceanogr. 32, 1365-1369, 1987.

Penkett, S., Jones, B., Brich, K., and Eggleton, A.: The importance of atmospheric ozone and hydrogen peroxide in oxidising sulphur dioxide in cloud and rainwater, Atmos. Environ., 13, 123 137, 1979.

Penkett, S. A., Bandy, B. J., Choularton, T. W., Chandler, A. S., Gallagher, M. W., Gay, M. J., Tyler, B. J., Dollard, G. J., and Jones, B. M. R.: Field measurement of the rate of oxidation of sulphur dioxide by hydrogen peroxide in a cap cloud, in: Proc. Symp. Role of Clouds in Atmospheric Chemistry and Global Climate, pp. J7-J10, AMS, Anaheim, CA, 1989.

Perros, P. E.: Large-scale distribution of hydrogen peroxide from aircraft measurements during TROPOZ II experiment, Atmos. Environ., 27, 1695-1708, 1993.

Pilz, W. and Johann, I.: Measurement of very small quantities of hydrogen peroxide in air, Int. J. Environ. Anal. Chem., 3, 257270, 1974.

Robbin Martin, L. and Damschen, D.: Aqueous oxidation of sulfur dioxide by hydrogen peroxide at low pH, Atmos. Environ., 15, 1615-1621, 1981.

Roeckner, E., Brokopf, R., Esch, M., Giorgetta, M., Hagemann, S., and Kornblueh, L.: Sensitivity of simulated climate to horizontal and vertical resolution in the ECHAM5 atmosphere model, J. Climate, 19, 3771-3791, 2006.

Salzmann, M., Lawrence, M. G., Phillips, V. T. J., and Donner, L. J.: Model sensitivity studies regarding the role of the retention coefficient for the scavenging and redistribution of highly soluble trace gases by deep convective cloud systems, Atmos. Chem. Phys., 7, 2027-2045, doi:10.5194/acp-7-2027-2007, 2007.

Sander, R., Kerkweg, A., Jöckel, P., and Lelieveld, J.: Technical note: The new comprehensive atmospheric chemistry module MECCA, Atmos. Chem. Phys., 5, 445-450, doi:10.5194/acp-5445-2005, 2005.

Sander, R., Baumgaertner, A., Gromov, S., Harder, H., Jöckel, P., Kerkweg, A., Kubistin, D., Regelin, E., Riede, H., Sandu, A., Taraborrelli, D., Tost, H., and Xie, Z.-Q.: The atmospheric chemistry box model CAABA/MECCA-3.0gmdd, Geosci. Model Dev. Discuss., 4, 197-217, doi:10.5194/gmdd-4197-2011, 2011.

Sander, S., Friedl, R., Golden, D., Kurylo, M., Huie, R., Orkin, V., Moortgat, G., Ravishankara, A., Kolb, C., Molina, M., et al.: Chemical kinetics and photochemical data for use in atmospheric studies, evaluation number 14, JPL Publ., National Aeronautics and Space Administration, Jet Propulsion Laboratory, California Institute of Technologies, Pasadena, CA, 02, 25, 334, 2003.

Schiller, C., Bozem, H., Gurk, C., Parchatka, U., Konigstedt, R., Harris, G., Lelieveld, J., and Fischer, H.: Applications of quantum cascade lasers for sensitive trace gas measurements of $\mathrm{CO}$, $\mathrm{CH}_{4}, \mathrm{~N}_{2} \mathrm{O}$ and HCHO, Appl. Phys. B, 92, 419-430, 2008.

Slemr, F. and Tremmel, H. G.: Hydroperoxides in the marine troposphere over the Atlantic Ocean, J. Atmos. Chem., 19, 371-404, 1994.

Snider, J. and Huang, J.: Factors influencing the retention of hydrogen peroxide and molecular oxygen in rime ice, J. Geophys. Res., 103, 1403-1415, 1998. 
Snider, J. R., Montague, D. C., and Vali, G.: Hydrogen peroxide retention in rime ice, J. Geophys. Res., 97, 7569-7578, 1992.

Snow, J., Heikes, B. G., Merrill, J. T., Wimmers, A. J., Moody, J. L., and Cantrell, C. A.: Winter-spring evolution and variability of $\mathrm{HO}_{x}$ reservoir species, hydrogen peroxide, and methyl hydroperoxide, in the northern middle to high latitudes, J. Geophys. Res., 108, 8362, doi:10.1029/2002JD002172, 2003.

Snow, J., Heikes, B., Shen, H., D. W. O'Sullivan, Fried, A., and Walega, J.: Hydrogen peroxide, methyl peroxide, and formaldehyde over North America and the North Atlantic, J. Geophys. Res., 112, D12S07, doi:10.1029/2006JD007746, 2007.

Stickler, A., Fischer, H., Williams, J., de Reus, M., Sander, R., Lawrence, M. G., Crowley, J. N., and Lelieveld, J.: Influence of summertime deep convection on formaldehyde in the middle and upper troposphere over Europe, J. Geophys. Res., 111, D14308, doi:10.1029/2005JD007001, 2006.

Stickler, A., Fischer, H., Bozem, H., Gurk, C., Schiller, C., Martinez-Harder, M., Kubistin, D., Harder, H., Williams, J., Eerdekens, G., Yassaa, N., Ganzeveld, L., Sander, R., and Lelieveld, J.: Chemistry, transport and dry deposition of trace gases in the boundary layer over the tropical Atlantic Ocean and the Guyanas during the GABRIEL field campaign, Atmos. Chem. Phys., 7, 3933-3956, doi:10.5194/acp-7-3933-2007, 2007.

Stuart, A. and Jacobson, M.: A timescale investigation of volatile chemical retention during hydrometeor freezing: Nonrime freezing and dry growth riming without spreading, J. Geophys. Res.Atmos., 108, 4178, doi:10.1029/2001JD001408, 2003.

Stuart, A. and Jacobson, M.: Chemical retention during dry growth riming, J. Geophys. Res.-Atmos., 109, D07305, doi:10.1029/2003JD004197, 2004.

Tost, H., Jöckel, P., Kerkweg, A., Sander, R., and Lelieveld, J.: Technical note: A new comprehensive SCAVenging submodel for global atmospheric chemistry modelling, Atmos. Chem. Phys., 6, 565-574, doi:10.5194/acp-6-565-2006, 2006.
Tost, H., Jöckel, P., Kerkweg, A., Pozzer, A., Sander, R., and Lelieveld, J.: Global cloud and precipitation chemistry and wet deposition: tropospheric model simulations with ECHAM5/MESSy1, Atmos. Chem. Phys., 7, 2733-2757, doi:10.5194/acp-7-2733-2007, 2007.

von Kuhlmann, R., Lawrence, M., Crutzen, P., and Rasch, P.: A model for studies of tropospheric ozone and nonmethane hydrocarbons: Model description and ozone results, J. Geophys. Res, 108, 4294, doi:10.1029/2002JD002893, 2003.

Walker, S. J., Evans, M. J., Jackson, A. V., Steinbacher, M., Zellweger, C., and McQuaid, J. B.: Processes controlling the concentration of hydroperoxides at Jungfraujoch Observatory, Switzerland, Atmos. Chem. Phys., 6, 5525-5536, doi:10.5194/acp-65525-2006, 2006.

Wang, C. and Crutzen, P. J.: Impact of a simulated severe local storm on the redistribution of sulfur dioxide, J. Geophys. Res., 100, 11357-11367, 1995.

Weinstein-Lloyd, J. B., Lee, J. H., Daum, P. H., Kleinman, L. I., Nunnermacker, L. J., Springston, S. R., and Newman, L.: Measurements of peroxides and related species during the 1995 summer intensive of the Southern Oxidants Study in Nashville, Tennessee, J. Geophys. Res., 103, 22361-22373, 1998.

Weller, R., Schrems, O., Boddenberg, A., Gb, S., and Gautrois, M.: Meridional distribution of hydroperoxides and formaldehyde in the marine boundary layer of the Atlantic $\left(48^{\circ} \mathrm{N}-35^{\circ} \mathrm{S}\right)$ measured during the Albatross campaign, J. Geophys. Res., 105, 14401-14412, 2000.

Yin, Y., Carslaw, K. S., and Parker, D. J.: Redistribution of trace gases by convective clouds - mixed-phase processes, Atmos. Chem. Phys., 2, 293-306, doi:10.5194/acp-2-293-2002, 2002. 